\title{
1. Making sense of forensic science evidence
}

\section{Paul Roberts*}

\section{SENSE AND METHODOLOGICAL SENSIBILITIES}

Making sense of puzzling phenomena is the stock-in-trade of academic research and scholarship; and I have been trying to make sense of forensic science evidence ever since I first became involved, largely through accidental good fortune, in researching this topic over a quarter of a century ago. ${ }^{1}$ At that time, in the early 1990 s, forensic science was highly newsworthy, partly owing to its implication in many of the

* This chapter draws together the threads and consolidates material that I have been working on for the last five years. It has benefitted from questions, discussion and debate in various formats and fora, including the following keynote presentations: 6th International Conference on Evidence Law and Forensic Science (ICELFS), Baltimore, USA (2017); Probability and Statistics in Forensic Science workshops, Newton Institute for Mathematical Sciences, Cambridge (2016); Northumbria University Centre for Evidence \& Criminal Justice Studies, Tenth Anniversary Symposium, Newcastle (2016); Australia and New Zealand Forensic Science Society (ANZFSS), 23rd International Symposium, Auckland (2016); Inaugural Meeting of the RSS Statistics and Law Section, Royal Statistical Society, London (2015); The Paradigm Shift for Forensic Science, The Royal Society, London (2015); 9th International Conference on Forensic Inference \& Statistics (ICFIS), Leiden University (2014). I am particularly grateful to my hosts on each occasion, respectively: David Fowler, Li Ling, Wang Zhuhao and Zhang Baosheng; Norman Fenton, David Lagnado, Martin Neil and Leila Schneps; Michael Stockdale; Sarah Scott; Colin Aitken; Sue Black and Niamh Nic Daeid; Charles Berger and Marjan Sjerps. For comments and suggestions on drafts, I am indebted to Gary Edmond, Michael Stockdale, Tony Ward and Tim Wilson.

1 Paul Roberts and Chris Willmore, The Role of Forensic Science Evidence in Criminal Proceedings, RCCJ Research Study No 11 (London, HMSO, 1993); Paul Roberts, 'Science in the Criminal Process' (1994) 14 Oxford Journal of Legal Studies 469. 
high-profile miscarriage of justice cases which resulted in the creation of the Runciman Royal Commission on Criminal Justice. ${ }^{2}$ The Royal Commission's Report $^{3}$ made numerous recommendations directly addressing forensic science and expert witnesses, ${ }^{4}$ some of which were subsequently implemented whilst others remain unfinished business. Plus ça change, plus c'est la même chose. Today, we are inundated with weighty policy analyses and reform recommendations from (amongst others) the US President's Advisory Council (PCAST), ${ }_{5}^{5}$ the National Academy of Sciences (NAS) ${ }^{6}$ and the Law Commission; ${ }^{7}$ serial amendments to the Criminal Procedure Rules and Criminal Practice Directions;

2 Discussed in Clive Walker and Russell Stockdale, 'Forensic Evidence' in Clive Walker and Keir Starmer (eds), Miscarriages of Justice: A Review of Justice in Error (London, Blackstone, 1999); Richard Nobles and David Schiff, Understanding Miscarriages of Justice (Oxford, Oxford University Press, 2000); Mike Redmayne, 'Expert Evidence and Scientific Disagreement' (1997) 30 UC Davis Law Review 1027; Carol AG Jones, Expert Witnesses: Science, Medicine and the Practice of Law (Oxford, Oxford University Press, 1994) ch 10.

3 Also see Roberts and Willmore, above n 1; Beverley Steventon, The Ability to Challenge DNA Evidence, RCCJ Research Study No 9 (London, HMSO, 1993); Graham Robertson, The Role of Police Surgeons, RCCJ Study No 6 (London, HMSO, 1993); Michael Zander and Paul Henderson, Crown Court Study, RCCJ Research Study No 19 (London, HMSO, 1993) 83-92; House of Lords Select Committee on Science and Technology, Fifth Report: Forensic Science (Chair: Lord Dainton) HL Paper 24, Session 1992-93 (London, HMSO, 1993).

4 Royal Commission on Criminal Justice (Chairman: Viscount Runciman), Report, Cm 2263 (London, HMSO, 1993) ch 9. For contemporary commentaries, see Paul Roberts, 'Forensic Science Evidence after Runciman' [1994] Criminal Law Review 780; Peter Alldridge, 'Forensic Science and Expert Evidence' (1994) 21 Journal of Law and Society 136; Mike Redmayne, 'The Royal Commission and the Forensic Science Market' in Mike McConville and Lee Bridges (eds), Criminal Justice in Crisis, (Aldershot, UK and Brookfield, VT, USA, Edward Elgar, 1994).

5 President's Council of Advisors on Science and Technology (PCAST), Report to the President: Forensic Science in Criminal Courts - Ensuring Scientific Validity of Feature-Comparison Methods (Washington DC, Executive Office of the President, 2016), https://obamawhitehouse.archives.gov/sites/ default/files/microsites/ostp/PCAST/pcast_forensic_science_report_final.pdf (accessed 31 January 2018).

6 National Research Council (NRC) of the NAS, Strengthening Forensic Science in the United States: A Path Forward (Washington DC, National Academies Press, 2009).

7 Law Commission, Expert Evidence in Criminal Proceedings in England and Wales, Law Com No 325 (London, TSO, 2011). 
and a burgeoning case law on expert evidence. Media interest in forensic science is undiminished, and the broader cultural fascination with all things 'forensic' has attracted its own cottage industry of sociological and jurisprudential analysis, under the tantalising rubric of the 'CSI Effect'. Contemporary forensic science boasts many strengths and striking successes, advertised to the world by its golden standard-bearer, ${ }^{9}$ forensic DNA profiling. Yet by the same token, forensic science has never been able to shake off its historical associations with miscarriages of justice, new examples of which are annually added to the expanding roster of causes célèbres. ${ }^{10}$

Tempting though it is to infer that nothing ever really changes, this conclusion would be hasty, myopic and intellectually lazy. In reality, the last quarter century has witnessed major, in some respects seismic, shifts in the forensic science landscape, affecting its institutional organisation

8 Christopher Lawless, Forensic Science: A Sociological Introduction (London, Routledge, 2016) ch 2; Simon A Cole and Rachel Dioso-Villa, 'Investigating the "CSI Effect" Effect: Media and Litigation Crisis in Criminal Law' (2009) 61 Stanford Law Review 1335; Hon Donald E Shelton, 'Juror Expectations for Scientific Evidence in Criminal Cases: Perceptions and Reality about the "CSI Effect" Myth' (2010) 27 Thomas M Cooley Law Review 1; Tom R Tyler, 'Viewing CSI and the Threshold of Guilt: Managing Truth and Justice in Reality and Fiction' (2006) 115 Yale Law Journal 1050.

9 Cf Michael Lynch, 'God's Signature: DNA Profiling, the New Gold Standard in Forensic Science' (2003) 27 Endeavour 93.

10 The latest reported scandal involves tampering with toxicology data potentially affecting thousands of criminal prosecutions: see Martin Evans, 'Forensics Lab Tests Tampering Probe Identifies 10,000 Criminal Cases that Might Have Been Affected', The Telegraph, 21 November 2017; Lizzie Dearden, 'Convictions in Doubt as More than 10,000 Cases Could be Affected by Data Manipulation at Forensics Lab: Scandal has Caused Drug Driving Cases to be Dropped and Deaths Referred to the Court of Appeal', The Independent, 21 November 2017. Generally, see Paul Roberts, 'Forensic Science and Criminal Justice' in Anthea Hucklesby and Azrini Wahidin (eds), Criminal Justice, 2nd edn (Oxford, Oxford University Press, 2013); Brandon L Garrett and Peter J Neufeld, 'Invalid Forensic Science Testimony and Wrongful Convictions' (2009) 95 Virginia Law Review 1; Jennifer Mnookin, 'Experts and Forensic Evidence' (2008) 37 Southwestern University Law Review 1009; Simon A Cole, 'The Prevalence and Potential Causes of Wrongful Conviction by Fingerprint Evidence' (2006) 37 Golden Gate University Law Review 39; Tony Ward, 'Experts, Juries, and Witch-Hunts: From Fitzjames Stephen to Angela Cannings' (2004) 31 Journal of Law and Society 369; Richard Nobles and David Schiff, "A Story of Miscarriage: Law in the Media' (2004) 31 Journal of Law and Society 221; JH Phillips and JK Bowen, Forensic Science and the Expert Witness (Sydney, The Law Book Co, 1985) ch 1. 
and regulation, professional training, modes of reasoning, and the legal processes and procedures through which forensic science evidence (and other expert witness testimony) is generated, presented, tested, evaluated and relied upon. Tectonic realignments have reverberated throughout England and Wales and the UK's other legal jurisdictions, across Europe, and around the world. Yet there remains the lingering sense, palpable to long-serving students of forensic science, that we seem to confront the same old issues, time and time again, going round in circles with little prospect of permanent satisfactory resolution. Studying forensic science sometimes feels like being trapped in an Escher sketch or an interminable season of Lost.

Having gradually perceived and reflected on this enigma, two explanatory factors strike me as paramount. First, forensic science is a complex issue. Indeed, it is not a single issue at all, but rather a bundle of multiple, partly overlapping issues giving rise to a variety of more-or-less related technological, institutional and regulatory challenges calling for context-sensitive, often fine-grained, policy engineering. Even a magazine full of silver bullets would not shoot this problem down (as if alleged silver bullets ever worked in criminal justice reform). A second macro-diagnostic insight is that forensic science and its institutional environments are constantly changing, resulting in the need for dynamic, as well as multifaceted, policymaking and agile, responsive professionalism in policy implementation. There can be no final resolution, because new problems, or new variants on old problems, are constantly arising from technological advances, institutional adjustments and shifting social attitudes, and they invariably demand innovative, bespoke solutions. This is interactive, four-dimensional policymaking. Recurrent issues can be stated at relatively high levels of abstraction. How can Law and Science successfully integrate their divergent cultures, methodologies and epistemological commitments? How can arcane science be explained intelligibly to non-experts? How can deference to scientific authority be squared with the normative principles of criminal adjudication? How can traditional procedural models be navigated, or adapted, to extract maximum value from forensic science? These and similarly abstract questions are relatively timeless, and this continuity accounts for old-timers' sense of déjà vu. But the policy choices these questions crystallise must constantly be reimagined and newly calibrated to contemporary circumstances, as perennial works in progress.

This chapter elaborates on the twin themes of complexity and dynamism in making sense of forensic science evidence. The first section develops the theme of complexity by exploring the 'problematic' of forensic science through a (slightly tongue-in-cheek) 'top 20 countdown' 
of prominent issues, problems and criticisms. The following section unravels the theoretical conundrum of how it can be rational for courts to rely on scientific expertise in criminal adjudication. We next turn to more concrete institutional questions, by reviewing the regulatory and procedural frameworks which govern the generation, presentation, testing and evaluation of forensic science evidence in England and Wales. Recent developments in institutional structures are highlighted and some jurisprudential refinements to orthodox accounts of procedural law are proposed. Finally, attention is given to the 'intellectual resources' and interpretative frameworks of forensic science, with particular reference to the contribution of 'Bayesian' approaches to forensic inference, evidence and proof.

\section{PROBLEMATISING FORENSIC SCIENCE}

There is no simple diagnostic tool for identifying 'the problem' of forensic science, or any neutral, agreed conceptual terminology in which to express it. As sociologists have long recognised, specifying the issues, problems and challenges constituting a particular field of inquiry - its 'problematic' - is an active, interpretative process requiring critical judgements, which are always informed by one's perspective, interests and purpose. ${ }^{11} \mathrm{~A}$ topic as thoroughly interdisciplinary as forensic science is bound to straddle divergent normative, epistemological and methodological frameworks, producing something of a terminological Babel - but also a very rich set of critical resources for research and scholarship. ${ }^{12}$

11 For elucidation, see Paul Roberts, 'Interdisciplinarity in Legal Research' in Mike McConville and Wing Hong Cui (eds), Research Methods for Law, 2nd edn (Edinburgh, Edinburgh University Press, 2017) (proposing the 'Eternal Triangle of Intellectual Inquiry' as a general heuristic for integrating subject matter, motivation and method in research).

12 For accessible entry points into a vast and expanding literature, see Paul Roberts (ed), Expert Evidence and Scientific Proof in Criminal Trials (Farnham, Ashgate, 2014); Susan Haack, Evidence Matters: Science, Proof, and Truth in the Law (Cambridge, Cambridge University Press, 2014); Philip Dawid, William Twining and Mimi Vasilaki (eds), Evidence, Inference and Enquiry (Oxford, Oxford University Press, 2011); Jim Fraser and Robin Williams (eds), Handbook of Forensic Science (Cullompton, Willan, 2009); Terrence Anderson, David Schum and William Twining, Analysis of Evidence, 2nd edn (Cambridge, Cambridge University Press, 2005); Jim Fraser, Forensic Science: A Very Short Introduction (Oxford, Oxford University Press, 2010). 
Self-awareness and transparency are the best guarantors of methodological rigour, since it would be self-defeating to deny one's own disciplinary projects, biases and preoccupations, and probably impossible to escape them entirely. ${ }^{13}$ Legal scholars tend to view forensic science from a criminal trial perspective, starting with the evidentiary product that might be produced in court or perhaps feature earlier in criminal investigations or prosecutions. A forensic scientist, contemplating how to formulate an investigative hypothesis or process a crime scene, might regard this as a curiously back-end or retrospective approach. But this is characteristic of how lawyers and courts typically conceptualise the issues, a perspective anchored in their respective institutional roles and responsibilities.

Contested trials seek to reconstruct events from the past, using evidence as an inferential bridge to support well-warranted conclusions about the events in question. Everything done during the investigation, prosecution and pre-trial phases of criminal proceedings is structured and regulated by the prospect of a contested trial. Even though the vast majority of cases are unsolved, not charged or prosecuted, or result in guilty pleas, it is not easy to predict which cases will comprise the minority that actually goes to trial, especially in the earlier stages when case information is typically incomplete and many uncertainties remain. Consequently, all evidence from crime scenes, complainants' statements, interviews with suspects and so forth, have to be collected, stored and processed in conformity with legal rules of admissibility or risk being challenged and rejected later should the case come to trial. Indeed, even the relatively remote prospect of critical scrutiny at trial can be seen to motivate conscientious compliance with procedural regulations in the vast majority of routine proceedings that are never contested. In this way, procedural and evidentiary rules that are applied in the courtroom influence the entirety of the process, disseminate a legal system's normative values and keep practitioners honest in their daily grind. So the natural history of a criminal case is like a film that can be played

13 Analogous methodological challenges of cultural perspective have long fascinated, and perplexed, comparative legal scholars (drawing on anthropological perspectives). See eg Gary Watt, 'Comparison as Deep Appreciation' in Pier Giuseppe Monateri (ed), Methods of Comparative Law (Cheltenham, UK and Northampton, MA, USA, Edward Elgar, 2012); Pierre Legrand, 'How to Compare Now' (1996) 16 Legal Studies 232; William Ewald, 'Comparative Jurisprudence (I): What Was it Like to Try a Rat?' (1995) 143 University of Pennsylvania Law Review 1898; David Nelken, 'Disclosing/Invoking Legal Culture: An Introduction' (1995) 4 Social \& Legal Studies 435. 
forwards or backwards, and can make sense in either direction. The best sense of it depends on where you stand in the process and what you need or want to know.

Any inquiry, no matter how pluralistic or reflexive, must begin somewhere; and a characteristically legal perspective is as good a starting point as any other. The following 'top 20' issues, problems and criticisms of forensic science evidence (listed in roughly logical sequence, rather than rank ordering of prevalence or significance) summarise recurrent themes in legal scholarship spanning many decades: ${ }^{14}$

1. Junk science: ${ }^{15}$ Particular forensic science techniques are invalid, in the straightforward sense that they do not 'work': tests do not measure what they purport to measure, and results do not show what they purport to show;

2. Unvalidated procedures and/or fallacious interpretative frameworks: Forensic science techniques lack adequate validation or logical (including probabilistic ${ }^{16}$ ) interpretative frameworks, compromising the reliability of analytical findings and/or the inferential conclusions supposedly based on them; ${ }^{17}$

3. Deficient evidence management: Forensic laboratories and practitioners lack adequate protocols and procedures to collect, preserve and process physical samples, free from contamination or problematic degradation or otherwise compromising the chain of custody;

14 This is a lightly reworked version of the 'top 20' presented and discussed in Paul Roberts, 'Paradigms of Forensic Science and Legal Process' (2015) 370 Philosophical Transactions B Article 20140256.

15 This provocative phrase is owed to Peter W Huber, Galileo's Revenge: Junk Science in the Courtroom (New York, Basic Books, 1991). Also see Paul C Giannelli, “Junk Science": The Criminal Cases' (1993) 84 Journal of Criminal Law and Criminology 105; David E Bernstein, 'Junk Science in the United States and the Commonwealth' (1996) 21 Yale Journal of International Law 123. 16 Ian Evett, 'The Logical Foundations of Forensic Science: Towards Reliable Knowledge' (2015) 370 Philosophical Transactions B Article 20140263; Graham Jackson, Colin Aitken and Paul Roberts, Case Assessment and Interpretation of Expert Evidence, Practitioner Guide No 4 (London, Royal Statistical Society, 2014), www.rss.org.uk/statsandlaw (accessed 31 January 2018).

17 Cf Ian W Evett et al, 'Expressing Evaluative Opinions: A Position Statement' (2011) 51 Science \& Justice 1; Michael J Saks, 'Forensic Identification: From a Faith-Based 'Science' to a Scientific Science' (2010) 201 Forensic Science International 14; Michael J Saks and Jonathan J Koehler, 'The Coming Paradigm Shift in Forensic Identification Science' (2005) 309 Science 892. 
4. Failures of applied scientific methodology: Particular tests or scientific opinions fail to meet 'scientific' standards of objectivity, independence and impartiality, with particular susceptibility to (unconscious) 'cognitive bias'; ${ }^{18}$

5. Human fallibility: Forensic scientists and expert witnesses make idiosyncratic mistakes (including mistaken data input);

6. Charlatanism: Experts are corrupt or incompetent charlatans;

7. Testimonial overreaching: Genuine experts stray beyond the bounds of their legitimate expertise in providing forensic opinions;

8. Structural process distortions: Sound science is corrupted by investigative practices and/or adversarial criminal procedure;

9. Lawyer mishandling: Lawyers and courts do not understand science properly, and consequently mishandle scientific evidence and/or abuse it for their own strategic ends;

10. Communication failures: Experts are incapable or unwilling to express themselves (orally or in writing) in a manner comprehensible to non-specialists;

11. Lax ('liberal') admissibility standards: Courts too readily admit questionable scientific evidence at trial, thus exposing factfinders to exaggerated risks of adjudicative error;

12. Excessively demanding ('conservative') admissibility standards: Courts too readily exclude novel or unconventional expert opinions, thus depriving factfinders of information relevant to their decision-making;

13. Testimonial silencing: Trial procedures for eliciting oral testimony prevent expert witnesses from communicating their evidence in their own language and on their own terms;

14. Adversarial deficit: There is inadequate scientific support for the defence throughout the pre-trial and/or trial process;

15. Manufactured disagreement: Adversarial trial procedures accentuate minor discrepancies between expert opinions, whilst obscuring substantial agreement;

18 Forensic Science Regulator, Guidance: Cognitive Bias Effects Relevant to Forensic Science Examinations, FSR-G-217 (Birmingham, FSR, 2015), www. gov.uk/government/publications/cognitive-bias-effects-relevant-to-forensic-scienceexaminations (accessed 31 January 2018); D Michael Risinger, Michael J Saks, William C Thompson and Robert Rosenthal, 'The Daubert/Kumho Implications of Observer Effects in Forensic Science: Hidden Problems of Expectation and Suggestion' (2002) 90 California Law Review 1. 
16. Institutionally incompetent to resolve genuine disagreement: Criminal trials are incompetent fora for attempting to resolve genuine scientific disagreements;

17. Excessive jury deference: Juries do not understand scientific evidence, and too easily defer to expert testimony;

18. Excessive jury scepticism: Juries do not understand scientific evidence, and consequently fail to credit expert testimony with the probative value it truly merits;

19. Number-blindness: ${ }^{19}$ In particular, laypeople do not understand the probabilistic or statistical basis of scientific evidence, producing localised versions of [17] and/or [18];

20. Two antithetical cultures: Law and Science are methodologically incompatible, dooming forensic science - as the misbegotten issue of a 'marriage of opposites' - to cope with a fundamentally conflicted personality. ${ }^{20}$

Evidently, this laundry list is an extraordinarily mixed bag. Some items overlap and their boundaries could easily be redrawn. Besides, in practice analytically discrete features are often interactive and potentially mutually aggravating or, alternatively, diametric tendencies might cancel each other out. Whilst some of the standard criticisms are more incisive or worrisome than others, they are all rooted in practical experiences of impropriety, mishaps and miscarriages of justice, and many are reinforced by the collective wisdom of wide-ranging official reviews and authoritative inquiries. $^{21}$

Of course, to err is only human, but that does not disqualify criticism [5] as fatuous. The ineradicable risk of human error points up the need for institutionally robust systems of triangulation, double-checking, oversight and effective management of human risk factors. That several of these criticisms are mutually contradictory - [11] and [12]; [17] and [18] - is an early clue to the scale and recalcitrance of the regulatory

19 Leila Schneps and Coralie Colmez, Math on Trial: How Numbers Get Used and Abused in the Courtroom (New York, Basic Books, 2013); Peter Hawkins and Anne Hawkins, 'Lawyers' Probability Misconceptions and the Implications for Legal Education' (1998) 18 Legal Studies 316.

20 Anita AK Wonder, 'Science and Law, a Marriage of Opposites' (1989) 29 Journal of the Forensic Science Society 75; Susan Haack, 'Irreconcilable Differences? The Troubled Marriage of Science and Law' (2009) 72 Law and Contemporary Problems 1; Stan Brown and Sheila Willis, 'Complexity in Forensic Science’ (2009) 1 Forensic Science Policy and Management 192, 196 (referring to a 'clash of two civilizations').

21 Notably including the NRC and PCAST reports, above nn 5-6. 
challenges posed by forensic science for the administration of criminal justice. It is highly unlikely that a single regulatory solution would be capable of addressing all, or even most, of these diverse and somewhat antagonistic concerns. Solutions to certain problems might simultaneously create or exacerbate other risks or shortcomings elsewhere in the system. Mutual misunderstanding, failures of communication and the (alleged) irrationalities of adversarial criminal procedure are constant refrains.

Forensic science is fundamentally an applied branch of scientific endeavour. Conventionally defined as 'science applied to the administration of justice', 22 forensic science serves the interests of justice - as specified by positive law and underpinned by normative political morality. Although forensic science is properly characterised for many practical purposes as a genuine partnership between scientists on the one hand and criminal investigators, lawyers and courts on the other, in terms of the structural logic of criminal adjudication science is properly subservient to legally defined objectives. This is why criticism [20], which superficially appears to expose a profound and enduring source of cultural estrangement distancing Science from Law, is not nearly as insightful as it seems. ${ }^{23}$ Granted that there are marked differences in the manner in which lawyers and scientists conduct their daily business and in their respective cultures and professional ideals, forensic science is - fundamentally and existentially - in the law business; ${ }^{24}$ and it cannot succeed, according to its own lights, unless scientific knowledge can be adapted to legal and broader justice requirements. 25

Law is inherently jurisdiction-specific, in a way that forensic science qua science is not. This primary conceptual and methodological distinction between Law and Science is not contradicted by the important further observation that forensic science qua forensic science is increasingly regulated by particularistic jurisdictional requirements (described in detail elsewhere in this volume) as well as by generic, universal criteria

22 JUSTICE (Chair HHJ Christopher Oddie), Science and the Administration of Justice (London, JUSTICE, 1991); JB Firth, 'Aspects of Forensic Science' [1954] Criminal Law Review 107.

23 Paul Roberts, 'Renegotiating Forensic Cultures: Between Law, Science and Criminal Justice' (2013) 44 Studies in the History and Philosophy of Biological and Biomedical Sciences 47.

24 Etymology is instructive: 'forensic' originally meant 'legal'.

25 See further, Paul Roberts, 'Making Forensic Science Fit for Justice' (2017) 49 Australian Journal of Forensic Sciences 502. 
of scientific method, sound knowledge and valid inference. Given forensic science's distinctive institutional location and objectives, the value and quality of forensic science evidence are always contextually variable, in the sense that what may constitute good evidence for justice in some places or cases would be useless or unacceptable in others. This pervasive sensitivity to institutional context threatens to turn any normative generalisation about forensic science or other expert evidence into indefensible dogma. Expert evidence of all kinds, even the testimony of an expert astrologer or magician, ${ }^{26}$ could conceivably be relevant and epistemically well-warranted in criminal proceedings, depending on the questions it addresses and the specific uses to which it is put.

Confronted with pronounced disciplinary diversity in forensic science and other expertise, it is tempting to think that particularised forms of expert evidence should ideally be governed by their own contextually adapted bespoke schemes of legal regulation. But this can only work if it is possible to specify operationally robust distinctions between different kinds of expert evidence. The most plausible generic division is between 'scientific' and 'non-scientific' expertise. ${ }^{27}$ However, US experience indicates that the science/non-science divide offers neither greater clarity nor less scope for controversy than the common law's orthodox expert/ non-expert dichotomy. ${ }^{28}$ The operative concept in English law remains 'expert', rather than 'science' or anything claiming similar methodological stringency. This approach endows the legal rules with maximum coverage and inclusivity: the substantive field and content of expert evidence could be just about anything, provided that it relates to a disputed question of fact at issue in the proceedings. If English criminal litigation is too conservative in its reception of novel or unorthodox science (criticism [12] in the 'top 20'), it is not because the formal rules of admissibility are too restrictive in defining 'experts'. A generic

26 In Moore $v$ Medley, The Times, 3 February 1955, the Court ruled that membership of the Inner Circle of Magic qualified a witness as 'a highly expert magician'. More prosaically, in $R v$ Chatwood [1980] 1 WLR 874, CA, known drug abusers were qualified to identify heroin. Also see $R v$ Hodges [2003] $2 \mathrm{Cr}$ App R 247, CA (police officer expert on the street price of heroin); $R v$ Faraz [2013] 1 WLR 2615, [2012] EWCA Crim 2820 (experts on Islam and terrorism).

27 The Law Commission was initially tempted by this dichotomy, but thought better of it after consultation: Law Com No 325, above n 7, paras 344-8 (concluding that '[i]t is difficult to disagree with these objections to our original dichotomy ... there should be just one set of generic factors').

28 D Michael Risinger, 'The Irrelevance, and Central Relevance, of the Boundary between Science and Non-Science in the Evaluation of Expert Witness Reliability' (2007) 52 Villanova Law Review 679. 
approach does, however, entail that the rules are written at a fairly high level of abstraction, often requiring significant interpretational effort to apply them contextually to the instant case.

On first principles, ${ }^{29}$ expert testimony adduced in criminal trials must be both (1) relevant to a live fact in issue (ie 'material' to the proceedings); and (2) not otherwise excluded by an applicable generic ${ }^{30}$ or expertise-specific exclusionary rule. 'Logic and common sense' are the overriding criteria of relevance in English law - a foundational precept of rationality in adjudication. It is conventionally said that expert evidence is admissible by way of exception to 'the opinion evidence rule', ${ }^{31}$ but this is an unhelpful and potentially misleading formalistic canard. It presupposes a clear distinction between 'facts' and 'opinions', where in reality there is a continuum defined by different levels of granularity in the description of factual inferences from observational data and perceptions. Like all other evidence, some expert witness testimony - for example, chemical analysis of suspected narcotics - lies towards the brute 'factual' pole of the continuum, whilst other testimony - for example, a medical diagnosis ${ }^{32}$ or assessment of the possibility and persistence of secondary transfer of physical traces ${ }^{33}$ - lies more towards the 'opinionated' pole. One might expect genuine experts to agree about scientific fact, whereas genuine differences of opinion are commonplace

29 For fuller treatments, see Paul Roberts and Adrian Zuckerman, Criminal Evidence, 2nd edn (Oxford, Oxford University Press, 2010) ch 11; Paul Roberts, 'The Science of Proof: Forensic Science Evidence in English Criminal Trials' in Fraser and Williams (eds), above n 12. For a contextual application, see Paul Roberts and Tony Ward, 'Expert Evidence in Trials of Sexual Offences' in Pamela Radcliffe, Gisli Gudjonsson, Anthony Heaton-Armstrong and David Wolchover (eds), Witness Testimony in Sexual Cases: Evidential, Investigative and Scientific Perspectives (Oxford, Oxford University Press, 2016).

30 Such as English law's general rules excluding improperly obtained evidence, hearsay, extraneous bad character, etc (all of which have fuzzy boundaries and/or multiple inclusionary exceptions and provisos). For systematic exposition and critical commentary, see Roberts and Zuckerman, above n 29.

31 See eg Colin Tapper, Cross and Tapper on Evidence, 12th edn (Oxford, Oxford University Press, 2010) 528 ('A witness may not give his opinion on matters calling for the special skill or knowledge of an expert unless he is an expert in such matters ...'); Ian Dennis, The Law of Evidence, 6th edn (Oxford, Oxford University Press, 2017) ch 20; Andrew LT Choo, Evidence, 4th edn (Oxford, Oxford University Press, 2015) 313; Roderick Munday, Evidence, 8th edn (Oxford, Oxford University Press, 2015) 321-37.

$32 \quad R v$ Henderson [2010] 2 Cr App R 24, [2010] EWCA Crim 1269.

$33 \quad R v$ Reed and Reed; $R v$ Garmson [2010] 1 Cr App R 23; [2009] EWCA Crim 2698. 
amongst specialists. But one might just as well say that scientific facts are just those matters about which genuine experts agree, whereas opinions allow for good faith disagreements between experts. There is, in other words, no independent criterion to arbitrate the institutionally constructed borderline differentiating facts from opinions.

Positive law defines the material 'issues' for criminal litigation in two distinct and cumulative ways. First, substantive criminal law specifies the elements of criminal offences that must be proved to secure a conviction, alongside general doctrines of liability, excuse and justification. The boundaries of substantive criminal liability differ in many significant details from one legal jurisdiction to another. Secondly, the matters in issue in particular criminal trials are further refined through situational combinations of criminal procedure law (including evidentiary rules of admissibility and exclusion), local practice and particular litigants' forensic strategies. These contingent aspects of procedure and practice tend to be significantly more diverse and influenced by local legal traditions than the scope and content of substantive criminal law. ${ }^{34}$ My 'top 20 countdown' is recognisably Anglophone, in explicitly referring to (and otherwise implicitly assuming) 'adversarial' trial procedure. The theory of adversarialism presupposes that the prosecution's case, including any expert evidence on which the prosecution proposes to reply, will be open to scrutiny and vigorous cross-examination by the defence, lending piquancy to criticism [14] regarding 'adversarial deficit'. Defence lawyers will not, in general, be able to conduct an informed evaluation of the strengths and weaknesses of scientific evidence adduced by the prosecution unless they can instruct their own well-qualified scientific advisors. Less adversarial (or 'inquisitorial'35) systems of criminal adjudication prefer to dispense with courtroom challenges to scientific evidence, characteristically relying on the uncontradicted evidence and advice of court-appointed experts. This manner of proceeding pre-empts some well-known difficulties - including the risks of adversarial distortion motivating criticisms [15] and [16] - but tends to create or exacerbate

34 Differences in substantive criminal law become more evident if we extend our comparative analysis beyond Western-style liberal democracies to include, eg, state socialism or theocratic government.

35 This is a convenient analytical construct, but its relationship to real-life legal systems is problematic and its implications are often misunderstood, especially by Anglophones. See further, Paul Roberts, 'Faces of Justice Adrift? Damaška's Comparative Method and the Future of Common Law Evidence' in John Jackson, Maximo Langer and Peter Tillers (eds), Crime, Procedure and Evidence in a Comparative and International Context (Oxford, Hart, 2008). 
mirror-image problems. Local commentators worry that inquisitorially minded judges too readily defer to the orthodox opinions of wellcredentialed experts, which consequently escape rigorous testing, potentially risking miscarriages of justice. ${ }^{36}$

Contrasts between 'adversarial' and 'inquisitorial' procedural models represent only one vector of comparative analysis. There are major differences in criminal procedure within the 'adversarial' and 'inquisitorial' procedural families. ${ }^{37}$ Indeed, it is common for civil (private law) and criminal adjudication to be conducted very differently within the same territorial jurisdiction. Expert evidence deemed adequate for one juridical purpose (eg family proceedings) may be inadmissible in a criminal trial, owing, for example, to more exacting fair trial and due process requirements and the higher standard of proof in criminal proceedings. Prosaic institutional realities must not be overlooked in comparative modelling. We need to be concerned not merely with the formalistic 'law in the books', but also with the sociological realities of 'the law in action'. Criticism [14], for example, is as much concerned with the availability of competent experts willing to take on defence work and the provision of state-funded legal aid to pay for them, as it is with overarching models of criminal procedure. Provision of legally aided defence expertise in the USA has always looked threadbare from a British perspective; ${ }^{38}$ though there is no room for self-satisfied complacency in this regard and it must be said that publicly funded defence forensics in English criminal proceedings have lately experienced the shock of austerity. Anticipating further cuts to the legal aid budget, criminal barristers have staged unprecedented courtroom walkouts and days of action. ${ }^{39}$ Our proud tradition of criminal justice will inevitably

36 See further, Vuille, Chapter 12 in this volume. Also see Joëlle Vuille, 'Admissibility and Appraisal of Scientific Evidence in Continental European Criminal Justice Systems: Past, Present and Future' (2013) 45 Australian Journal of Forensic Sciences 389; Chrisje Brants, 'Wrongful Convictions and Inquisitorial Process: The Case of the Netherlands' (2012) 80 University of Cincinnati Law Review 1069; Bron McKillop, 'Forensic Science in Inquisitorial Systems of Criminal Justice' (1995) 7 Current Issues in Criminal Justice 36.

37 See Paul Roberts and Jill Hunter (eds), Criminal Evidence and Human Rights: Reimagining Common Law Procedural Traditions (Oxford, Hart, 2012) (advocating 'common law comparativism').

38 Cf Paul C Giannelli, 'Ake v Oklahoma: The Right to Expert Assistance in a Post-Daubert, Post-DNA World' (2004) 89 Cornell Law Review 1305.

39 Owen Bowcott, 'Criminal Solicitors to Walk Out for Third Time over Legal Aid Cuts', The Guardian, 21 March 2014; Owen Bowcott and Nicola Brown, 'More than 1,000 Lawyers Protest Outside Parliament at Legal Aid Cuts: 
become impoverished if we are not, as a society and as a political culture, prepared to pay what it costs. Criminal adjudication is not a "public service' in the same way as road maintenance, or public libraries, or street lighting, or tertiary education or even our beloved National Health Service, whereby the government in extremis might say: 'I'm sorry, you can't have any more, the money has run out.' Normative constraints of justice, as well as English common law and European human rights law, preclude us from saying to the accused: 'Since we cannot afford to give you a fair trial, you are going to get an unfair one, instead.'

Traditional theories of legal jurisdiction are starting to creak under the weight of globalisation and cosmopolitan jurisprudence. Today, law characteristically travels, crosses borders, engages in transnational conversations; and as law impacts on the places it visits, so in its turn law is affected by, and adapts in response to, its cosmopolitan institutional and cross-cultural adventures. ${ }^{40}$ Law reformers, no less than practitioners, must engage with dynamic legal environments, in which the power of states to legislate and regulate has been curtailed by global political, economic and social forces. Forensic science, for example, is now subject to aspects of pan-European regulation and cross-border cooperation. ${ }^{41}$

Former Tory MP Sir Ivan Lawrence QC tells Protesters He is Ashamed of Government for "Destroying Criminal Justice System"', The Guardian, 8 March 2014 (quoting Nigel Lithman QC, chairman of the (barristers') Criminal Bar Association, as saying: 'If these cuts are not addressed then the British justice system, which is held in such high esteem around the world, will cease to exist as we know it and the British public can no longer expect true justice to be delivered').

40 For some useful entry points into the burgeoning and disparate literature, see Roger Cotterrell, 'What is Transnational Law?' (2012) 37 Law \& Social Inquiry 500; William Twining, Globalisation and Legal Theory (London, Butterworths, 2000); Valsamis Mitsilegas, Peter Alldridge and Leonidas Cheliotis (eds), Globalisation, Criminal Law and Criminal Justice: Theoretical, Comparative and Transnational Perspectives (Oxford, Hart, 2015); Paul Roberts, 'Comparative Criminal Justice Goes Global' (2008) 28 Oxford Journal of Legal Studies 369; David Nelken (ed), Comparative Criminal Justice and Globalisation (Farnham, Ashgate, 2011).

41 See McCartney and Graham, Chapter 13 in this volume. Also see Alex Biedermann, Christophe Champod and Sheila Willis, 'Development of European Standards for Evaluative Reporting in Forensic Science: The Gap between Intentions and Perceptions' (2017) 21 International Journal of Evidence \& Proof 14; Filipe Santos and Helena Machado, 'Patterns of Exchange of Forensic DNA Data in the European Union through the Prüm System' (2017) 57 Science \& Justice 307; Tim J Wilson, 'Criminal Justice and Global Public Goods: The Prüm Forensic Biometric Cooperation Model' (2016) 80 Journal of Criminal Law 303. 
Without wishing to downplay the juridical and practical significance of these developments, however, modern criminal law has retained its national (or state) default-setting, and jurisdiction remains a crucial legal vector. In particular, the generation, admissibility and uses of forensic science evidence are still predominantly regulated by national courts. One must always be wary of overgeneralising from the peculiarities of individual legal systems or casually extrapolating from one legal jurisdiction to another, in ignorance or denial of potentially significant procedural, cultural or practical differences.

\section{RATIONAL RELIANCE ON SCIENTIFIC EXPERTISE42}

A hallmark of all modern ${ }^{43}$ trial systems is that they aspire to rationality in their adjudicative findings. Verdicts in criminal trials are supposed to be based on reliable evidence and verified to a demanding standard of proof. Juries must not find defendants guilty on mere speculation, whim, superstition or innuendo. Twining influentially traced a 'rationalist tradition' in Evidence scholarship to the birth of Enlightenment jurisprudence. ${ }^{44}$ On the face of it, scientific evidence seems to comport well with these rationalist aspirations. Science promises to provide the best explanations of empirical phenomena and to supply factfinders with reliable information to resolve disputed questions of fact. However, this congruence is not quite as complete or comfortable as might be imagined. The rationality pervading criminal adjudication is best interpreted as a normative rationality of criminal justice, rendering reliance on scientific expertise potentially problematic in various ways.

Criminal trials are practical exercises in reasoning under uncertainty. We want to know what happened; but material facts are contested (otherwise the accused would have pleaded guilty in common law systems). Relevant evidence rationally authorises or 'warrants' particular inferential conclusions. The more probative value evidence has, the more

42 This section draws on Paul Roberts, 'LTDNA Evidence on Trial' (2016) 7 Frontiers in Genetics Article 180.

43 Pre-modern systems also aspired to rationality in their own terms. Cf Mirjan Damaška, 'Rational and Irrational Proof Revisited' (1997) 5 Cardozo Journal of International and Comparative Law 25; Hock Lai Ho, 'The Legitimacy of Medieval Proof' (2004) 19 Journal of Law \& Religion 259.

44 William Twining, 'The Rationalist Tradition of Evidence Scholarship' in Enid Campbell and Louis Waller (eds), Well and Truly Tried (Sydney, The Law Book Company, 1982); reprinted in William Twining, Rethinking Evidence, 2nd edn (Cambridge, Cambridge University Press, 2006) ch 3. 
warrant it provides for the conclusion. In traditional common law thinking, the best evidence is the oral testimony of a percipient witness, given on oath and tested through cross-examination. This category of evidence is regarded as providing the best epistemic warrant for the inferential conclusions supported by the witness's testimony. This does not mean to say, of course, that every witness in court is truthful, accurate and reliable. We know, for example, that there can be many kinds of difficulty with eyewitness testimony. ${ }^{45}$ But it does not follow, as a general proposition, that we should therefore prefer the testimony of those who did not see the incident to testimony from witnesses who did. 'Best' does not mean infallible. Evidence adduced in criminal trials is often contested or contradictory, and the factfinder must make the best of it, resolving any enduring doubts in accordance with the applicable burden and standard of proof. In criminal litigation, most (not all) doubts are resolved in favour of the accused, in accordance with the presumption of innocence. ${ }^{46}$

Expert evidence supplies inferential warrant through the argument from authority. The expert says to the court, trust me, I'm an expert. The rationality of reliance on expertise is a very old intellectual and practical problem. It appears as a paradox or dilemma in ancient philosophy, was typically characterised as fallacious in twentieth-century studies of formal logic, but has more recently attracted sympathetic reconstructions from epistemologists and theorists of argumentation exploring defeasible (probabilistic) reasoning. ${ }^{47}$ Stripped down to its bare essentials, the authority paradigm underpinning the inferential logic of forensic expert

45 See eg Richard A Wise, Clifford S Fishman and Martin A Safer, 'How to Analyze the Accuracy of Eyewitness Testimony in a Criminal Case' (2009) 42 Connecticut Law Review 435.

46 The leading case in English law is (still) Woolmington $v$ DPP [1935] AC 462, HL. However, the concept of 'presumption of innocence' is complex and open to a range of normative and epistemic interpretations. See further, Paul Roberts, 'Loss of Innocence in Common Law Presumptions' (2014) 8 Criminal Law and Philosophy 317; Richard L Lippke, Taming the Presumption of Innocence (New York, Oxford University Press, 2016); Liz Campbell, 'Criminal Labels, the European Convention on Human Rights and the Presumption of Innocence' (2013) 76 Modern Law Review 681; Andrew Stumer, The Presumption of Innocence (Oxford, Hart, 2010).

47 See eg Douglas Walton, Appeal to Expert Opinion: Arguments from Authority (University Park PA, Penn State University Press, 1997); Alvin I Goldman, 'Experts: Which Ones Should You Trust?' (2001) 63 Philosophy and Phenomenological Research 85; Douglas Walton and Nanning Zhang, 'An Argumentation Interface for Expert Opinion Evidence' (2016) 29 Ratio Juris 59. 
testimony can be modelled to comprise five major components: (1) the expert is a genuine expert (competence); (2) in a field in which expertise can be obtained (domain); (3) and has correctly and conscientiously applied authentic domain-specific protocols to produce proffered evidence (methodological validity); (4) in relation to a legally relevant issue (materiality); (5) and in a form that is likely to provide legitimate epistemic warrant for legal adjudication (admissibility and probative value). The authority paradigm is generic. It applies to 'sciences' as conventionally understood (and in idiomatic English, this generally means 'the hard sciences' like physics and chemistry), but also to historical, social and psychological facts, and even to moral and theological reasoning. This fivefold taxonomy, albeit a necessarily simplifying model, offers a powerful heuristic for teasing out theoretical complexities and practical challenges entailed by the familiar-sounding notion of forensic expertise. ${ }^{48}$ For example, components (1) to (3) competence, domain and methodological validity - interact in interesting ways. The authority paradigm obviously breaks down if the testimony is not proffered by a genuine expert; if the so-called expert is an incompetent' witness in the common lawyer's sense (item [6] on the forensic 'top $20^{\prime}$ ). But sometimes, it is not so much the qualifications and experience of individual experts that are at stake, but the very possibility of domain expertise. The objection to 'expert' witch-finders ${ }^{49}$ or ghost hunters is more fundamental (and less ad hominem) than any criticism that individual exponents have not taken the appropriate training courses or gained enough job-related experience.

Methodological validity, component (3), embraces a set of important epistemic considerations arising even in relation to genuine experts in well-established disciplinary domains. The authority paradigm breaks down for different reasons when genuine experts succumb to personal or professional biases, fail to implement pertinent methodological protocols correctly, or purport to speak beyond the boundaries of their domainspecific expertise (respectively, [4], [5] and [7] on the 'top 20' countdown). It may be difficult in the general run of cases for courts to

48 Also see Susan Haack, Evidence Matters: Science, Proof and Truth in the Law (Cambridge, Cambridge University Press, 2014); Harry Collins, Are We All Scientific Experts Now? (Cambridge, Polity, 2014); Harry Collins and Robert Evans, Rethinking Expertise (Chicago, Chicago University Press, 2007).

49 Cf Malcolm Gaskill, 'Witchcraft and Evidence in Early Modern England' (2008) 198 Past and Present 33; Gregory Durston, Witchcraft and Witch Trials: A History of English Witchcraft and its Legal Perspectives, 1542 to 1736 (Chichester, Barry Rose, 2000). 
differentiate between genuinely well-credentialed experts, and plausiblesounding charlatans and shysters. ${ }^{50}$ This practical challenge is so much greater, however, in relation to the types of failing encompassed by component (3), where genuine experts are overreaching in one way or another. $^{51}$ Forms of expert testimony incorporating multiple specialist domains, such as DNA profiling, pose these dilemmas acutely. Plainly, not every opinion or judgement expressed by an expert properly qualifies as expert opinion. Judges may be ill-equipped and trial procedure ill-suited to policing experts' disciplinary boundaries effectively.

Components (4) and (5) of the authority paradigm - materiality and admissibility/probative value - introduce further major complexities, in terms of managing the interface between expert knowledge and forensic objectives, concerns and values. A vital distinction is that, whereas components (1) to (3) are essentially epistemic matters, criminal adjudication is fundamentally normative. The overriding objective of criminal proceedings is doing justice; 52 and whilst epistemic considerations are vital ingredients in the mix - we want to convict the guilty, and only them, of the right offence(s) - epistemology is not the proof of the pudding. We only want to convict the guilty in the right way ('by due process of law'), not any which way - for example, by vigilante lynch mob or Dirty Harry policing ${ }^{53}$ in violation of the rule of law. Thus, all evidence, including expert witness testimony, must satisfy fundamental criteria of procedural fairness, transparency, exposure to adversarial

50 Although in no sense representative, the literature contains examples of truly egregious malpractice in pockets of forensics: see eg Paul C Giannelli, 'The Abuse of Scientific Evidence in Criminal Cases: The Need for Independent Crime Laboratories' (1997) 4 Virginia Journal of Social Policy and the Law 439.

51 Cf Meadow v General Medical Council [2007] QB 462, [2006] EWCA Civ 1390; Richard Nobles and David Schiff, 'Misleading Statistics within Criminal Trials: The Sally Clark Case' (2005) 2(1) Significance 17.

52 Criminal Procedure Rules 2015, r.1. For broader contextualising discussion, see Paul Roberts, 'Groundwork for a Jurisprudence of Criminal Procedure' in RA Duff and Stuart Green (eds), Philosophical Foundations of Criminal Law (New York, Oxford University Press, 2011).

53 Cf Joëlle Anne Moreno, 'What Happens when Dirty Harry Becomes an (Expert) Witness for the Prosecution?' (2004) 79 Tulane Law Review 1; Richard Nobles and David Schiff, 'Due Process and Dirty Harry Dilemmas: Criminal Appeals and the Human Rights Act' (2001) 64 Modern Law Review 911; Michael Stokes Paulsen, 'Dirty Harry and the Real Constitution' (1997) 64 University of Chicago Law Review 1457; Carl B Klockars, 'The Dirty Harry Problem' (1980) 452 Annals of the American Academy of Political and Social Science 33. 
testing, and compliance with other basic criteria of the right to a fair trial. In European jurisdictions, traditional procedural guarantees are now reinforced by human rights law. ${ }^{54}$

It is at this point in the discussion that, in my experience, lawyers and scientists tend to see things differently; and misunderstandings easily arise. Science investigates empirical matters, and produces factual information about the world. It is epistemic to its core and overwhelmingly instrumental in outlook. The policy paradigm is 'curing cancer'. A new drug either works (in part), or it does not. It has particular side effects (in some degree), or it does not. It can be manufactured by a particular process, or it cannot. Likewise, the DNA collected from the crime scene was either deposited by the accused, or by somebody else; the accused lacked capacity to form the required intention at the material time (eg because catatonic or sleepwalking), or he did not; and so on. These are all facts about the (empirical) world; they are either true or false; and they invoke or presuppose causal explanations. This is not to imply that 'science' always provides unequivocal, certain answers to discrete, wellformulated questions. To the contrary, scientific investigation is inherently uncertain ('experimental'), and conclusions are typically framed in probabilistic terms - whether or not employing explicitly quantitative measurements of uncertainty in numbers or words. But the equivocation introduced by resorting to probability is epistemic not ontological: it relates to the status of our knowledge and beliefs about facts in the world, not to the facts themselves (setting aside complications arising from quantum physics and sub-atomic particles not pertinent to the present discussion). Judgements of justice are of an entirely different, normative, order. It is not merely doubtful or uncertain whether, say, it would be just or fair if Drug X cured cancer; or just or fair if the accused were the donor of crime scene DNA. Such questions are incoherent. They perpetrate a category error, confusing normative standards with empirical facts.

Criminal adjudication comprises a set of institutionalised practices for determining liability and censuring and punishing criminal wrongdoing. ${ }^{55}$

54 For general elucidation, see John D Jackson and Sarah J Summers, The Internationalisation of Criminal Evidence (Cambridge, Cambridge University Press, 2012); Roberts and Hunter (eds), above n 37.

55 Generally, see Paul Roberts (ed), Theoretical Foundations of Criminal Trial Procedure (Farnham, Ashgate, 2014); Antony Duff, Lindsay Farmer, Sandra Marshall and Victor Tadros, The Trial on Trial Volume Three: Towards a Normative Theory of the Criminal Trial (Oxford, Hart, 2007); AP Simester and Andreas von Hirsch, Crimes, Harms and Wrongs (Oxford, Hart, 2011). 
This set of practices is normative through and through. It is not just that epistemic considerations are subject to normative side-constraints, as where we exclude relevant evidence procured by torture irrespective of its epistemic credentials. ${ }^{56}$ Epistemic objectives are themselves normatively constituted, in the sense that the standard of adequate epistemic warrant is indexed to the institutionalised practices and objectives of criminal adjudication. So what we require is not 'adequate warrant' (sufficient grounds) in the abstract, but adequate warrant for the purposes of determining criminal liability and censuring and punishing criminal wrongdoers. By reframing the issue in this way, it should become clearer why expert evidence cannot provide its own epistemic warrant for judicial purposes, no matter how highly the evidence scores on components (1)-(3) of the authority paradigm. Expert witnesses do not decide what evidence is 'good enough' for the purposes of criminal adjudication. This is the role of the legally, indeed constitutionally, authorised factfinder. Furthermore, issues of materiality and strategic application in individual cases are determined by legal standards and judicial decision-makers, not by the disciplinary standards embraced by particular sciences or expert witnesses. This insight goes to the heart of the truism that forensic science serves justice, not the other way around.

The logic of the authority paradigm and the priority of normative over epistemic considerations in criminal adjudication are general features of all modern legal systems. Detailed policies and procedures for organising the resulting interfaces, exploiting opportunities and managing tensions, however, vary considerably, working with the grain of local procedural traditions, institutional practices and professional cultures. For example, in the common law world lay fact-finding is still regarded as significant (even though professional judges increasingly predominate), whilst lay input in criminal adjudication is diminished or even non-existent in most Continental juristic traditions. The roles, relationships and distribution of powers between judges, prosecutors and defence lawyers also vary considerably across legal jurisdictions. In legal systems with stronger adversarial leanings, prosecutors and defence lawyers tend to play a more active role in shaping the course of the proceedings, whereas the 'inquisitorial' judge is the dominant figure in other procedural models. Criminal procedure is dynamic and constantly evolving (we have seen

56 A v Secretary of State for the Home Department (No 2) [2006] 2 AC 221, [2005] UKHL 71; Gäfgen v Germany (2011) 52 EHRR 1, ECtHR (GC). For discussion, see Paul Roberts, 'Normative Evolution in Evidentiary Exclusion: Coercion, Deception and the Right to a Fair Trial' in Roberts and Hunter (eds), above $\mathrm{n} 37$. 
major shifts towards a philosophy of activist judicial trial management in England and Wales in recent years, for example ${ }^{57}$ ), and it is always perilous to overgeneralise abstract formal models or to extrapolate too confidently from national traditions. It follows that approaches to expert evidence in general, or to particular types of scientific evidence, which are utilised successfully in one jurisdiction cannot automatically be expected to operate with the same success, or at all, in a different procedural environment structured by local normative priorities. This observation holds irrespective of the epistemic credentials of expert evidence (authority paradigm components (1)-(3)). Normative pluralism and jurisdictional diversity are inherent features of modern legality requiring detailed local knowledge and careful negotiation, not least on the part of expert witnesses operating in multiple jurisdictions. These elements of cultural relativity tend to provoke intuitive resistance from scientists accustomed to prioritising universal (empirical) scientific truth over national ideology. In one sense, scepticism is justified: sacrificing science to ideology in general, and regardless of political variety, leads to Lysenkoism, authoritarianism, crop failure and mass starvation. Nonetheless, the subservience of science to normative criteria is an inherent, fully rationalised and legitimate requirement of penal justice.

Two kinds of recurrent problems with expert evidence call for practical solutions in all legal systems. The first is the problem of expert disagreement; the second, more fundamental problem, concerns a familiar dynamic between deference and education. What should a court do when expert witnesses disagree? An attractive first option would be to find that, on further investigation, there is no genuine disagreement to resolve, for example, because one of the protagonists is not really an expert after all, or not an expert in the relevant domain, or because the experts have been fed different factual assumptions by their instructing lawyers, and once these discrepancies have been clarified the ostensible disagreement disappears. But this convenient resolution will not always be possible. In cases of genuine, well-informed, unshakeable disagreement between experts, various strategies are available to the court. One

57 For critical commentaries, see Ed Johnston, 'All Rise for the Interventionist: The Judiciary in the 21st Century' (2016) 80 Journal of Criminal Law 201; Mike McConville and Luke Marsh, 'Adversarialism Goes West: Case Management in Criminal Courts' (2015) 19 International Journal of Evidence \& Proof 172; Fae Garland and Jenny McEwan, 'Embracing the Overriding Objective: Difficulties and Dilemmas in the New Criminal Climate' (2012) 16 International Journal of Evidence \& Proof 233. 
approach would be to accept the disagreement as a forensically significant fact in and of itself and resolve the issue in accordance with the burden and standard of proof (usually, but not invariably, giving the accused the benefit of the doubt in a criminal trial). ${ }^{58}$ A second strategy would be to side-step scientific disagreements by invoking individual experts' respective qualifications, experience and/or testimonial credibility as proxies for the reliability of their evidence, for example, by adopting the working assumption that the professor or consultant is more likely to be correct than a laboratory technician or medical student. A third possibility is for the court to try to resolve the disagreement for itself. Strategies two and three exemplify the education/deference dynamic in factfinders' reliance on expert evidence. ${ }^{59}$ Strategy two entails deferring to the most authoritative expert, as judged by the factfinder (with or without the benefit of further judicial directions). The third strategy initially sounds the most attractive, because it comports with the factfinder's overarching responsibility for determining disputed questions of fact. The obvious problem is that, by definition, the factfinder lacks domain-specific expertise. Can the experts, through their courtroom testimony, effectively educate the factfinder to arrive at its own decision? Perhaps some element of 'education' is possible, even in the constrained and most unpromising pedagogical environment of the criminal courtroom, but it seems quite implausible that factfinders in criminal trials could be equipped with sufficient knowledge and insight to resolve disputes between genuine experts with long years of study and extensive practical experience. ${ }^{60}$ Worse, factfinders' lack of domain-relevant expertise also undercuts strategy two, because how is it possible for jurors to

58 This strategy was suggested in $R v$ Cannings [2004] 1 WLR 2607, [178] (CA), where Judge LJ advised prosecutors and trial judges that if the outcome of the trial depends exclusively or almost exclusively on a serious disagreement between distinguished and reputable experts, it will often be unwise, and therefore unsafe, to proceed'. But cf $R v$ Hookway and Noakes [2011] EWCA Crim 1989.

59 Ronald J Allen and Joseph S Miller, 'The Common Law Theory of Experts: Deference or Education?' (1993) 87 Northwestern University Law Review 1131.

60 These issues have been extensively debated in the legal literature: see eg Ronald J Allen, 'Expertise and the Daubert Decision' (1994) 84 Journal of Criminal Law and Criminology 1157; Edward J Imwinkelreid, 'The Next Step in Conceptualizing the Presentation of Expert Evidence as Education: The Case for Didactic Trial Procedures' (1997) 1 International Journal of Evidence \& Proof 128; Gary Edmond, 'The Next Step or Moonwalking? Expert Evidence, the Public Understanding of Science and the Case against Imwinkelreid's Didactic 
assess the comparative merits of experts' disagreements when their own knowledge of the field is tenuous or non-existent? The worry is that, in the absence of rational criteria for making a determination, factfinders will fall back on irrational proxies for robust epistemic warrant, such as placing their faith in the expert with greater testimonial eloquence or the doctor with the most reassuring bedside manner.

Legal systems resolve these pervasive issues of expertise in their own distinctive ways. At the level of sweeping generalisation, common lawyers tend to think that 'civilians don't try' 61 and that inquisitorial judges too readily defer to authoritative court-appointed experts. ${ }^{62}$ Civilians, for their part, tend to regard common law criminal procedure as irrational in its preferences for adversarial theatre, excessive technicality and lay over expert (including expert judicial) decision-making. ${ }^{63}$ These longstanding debates implicate deep-rooted and enduring controversies. Suffice it here to say that there is no reason for thinking that structures and cultures of criminal adjudication must conform to a single uniform pattern (so long as they adhere to fundamental standards of justice), any more than we should expect rigid, monotonous uniformity in national cuisine, language or other expressions of cultural identity. Recognition of

Trial Procedures' (1998) 2 International Journal of Evidence \& Proof 13; Edward J Imwinkelreid, 'Correspondence: Didactic Trial Procedures' (1998) 2 International Journal of Evidence \& Proof 205; Anthony Kenny, 'The Expert in Court' (1983) 99 Law Quarterly Review 197.

61 William Twining, 'Civilians Don't Try: A Comment on Mirjan Damaska's "Rational and Irrational Proof Revisited"' (1997) 5 Cardozo Journal of International and Comparative Law 69.

62 MN Howard QC, 'The Neutral Expert: A Plausible Threat to Justice' [1991] Criminal Law Review 98. Such stereotypes are not without empirical foundation: cf Brants, above n 36, 1111 (observing that '[j]udges may be inclined to give too much weight to expert testimony and forensic evidence (especially true of DNA). ... [I]t is perhaps more problematic that judges will generally have at their disposal the evidence of only one expert. ... [T] he routine absence of an expert for the defence means that the court is dependent upon its own, often amateur, evaluation of the evidence'). Also see Vuille, Chapter 12 in this volume.

63 See further, JR Spencer, 'Court Experts and Expert Witnesses: Have We a Lesson to Learn from the French?' (1992) 45 Current Legal Problems 213; William T Pizzi, Trials Without Truth (New York, NYU Press, 1999); Gordon van Kessel, 'Adversary Excesses in the American Criminal Trial' (1992) 67 Notre Dame Law Review 403; Mirjan R Damaška, The Faces of Justice and State Authority: A Comparative Approach to the Legal Process (New Haven, Yale University Press, 1986). 
legitimate scope for jurisdictional diversity, even in procedural fundamentals, is another major respect in which international, interdisciplinary conversations about law and justice differ markedly from international conversations about science and expertise.

\section{REGULATORY AND PROCEDURAL FRAMEWORKS IN ENGLAND AND WALES}

Expert evidence, of fact or opinion, is admissible in English criminal trials when it is both relevant and helpful ${ }^{64}$ to the factfinder in discharging its adjudicative responsibilities. Unhelpful expert testimony is superfluous at best, and possibly worse than useless in potentially confusing the issue and imposing avoidable litigation costs. Such evidence is inadmissible, not only at law, but also as a direct extrapolation of basic canons of rationality. 'Helpfulness' is a flexible standard requiring fact-sensitive contextual application. Trial judges are sometimes called upon to make close judgement calls, weighing up the anticipated probative value of the evidence in resolving disputed facts, against its potential for mischief, muddle or misdirection. The Court of Appeal is unlikely to interfere, unless the trial judge's decision has strayed off into what English lawyers call 'Wednesbury unreasonableness'. ${ }^{65}$ Besides, individual admissibility determinations (including those upheld on appeal) are not, for the most part, formal legal precedents, but rather contextual applications of settled legal principles. ${ }^{66}$

$64 \quad R v$ Turner [1975] QB 834, CA; $R$ v Clarke (Robert Lee) [1995] 2 Cr App $\mathrm{R}$ 425, 429-30, CA; $R$ v Hurst [1995] 1 Cr App R 82, CA; $R$ v Francis [2013] EWCA Crim 123, [38]-[39].

65 Decisions are unreasonable (or 'irrational') in the Wednesbury sense if they fail to take into account relevant considerations, incorporate irrelevant considerations or arrive at a conclusion that no reasonable decision-maker, properly appraising salient facts, could have reached: see eg Callander $v$ DPP [2002] EWHC 1523 (Admin). Judicial review ensures that so-called 'discretionary' decisions are actually an exercise of judgement by the appropriate decisionmaker.

66 Cf Mike Redmayne, Paul Roberts, Colin Aitken and Graham Jackson, 'Forensic Science Evidence in Question' [2011] Criminal Law Review 347 (taking a more pragmatic, somewhat less alarmist view of $R v T$ [2011] $1 \mathrm{Cr}$ App R 9, [2010] EWCA Crim 2439 than many other commentators). 
Commentators have repeatedly criticised the common law's approach to expert evidence, especially its supposed laxity and obscurity, ${ }^{67}$ and pressure for statutory reform had been building for some time. After a wide-ranging consultation exercise, the Law Commission of England and Wales proposed the introduction of a new, more rigorous admissibility framework for expert evidence. ${ }^{68}$ However, the Government declined to enact the Commission's proposals, largely on grounds of the anticipated cost of additional admissibility hearings. Instead, the Consolidated Criminal Practice Direction was amended to spell out a range of methodological and contextual factors to which trial judges should have regard when assessing the reliability of 'expert opinion evidence', as a precondition to its admissibility. ${ }^{69}$ The revised Practice Direction stresses that '[n]othing at common law precludes assessment by the court of the reliability of an expert opinion by reference to substantially similar factors to those the Law Commission recommended as conditions of admissibility, and courts are encouraged actively to enquire into such factors' ${ }^{70}$ In other words, trial judges already have the responsibility at common law, flowing from the elementary principles of relevance and helpfulness, to scrutinise the methodological credentials of scientific or other expert evidence. ${ }^{71}$

67 See eg Andrew Roberts, 'Drawing on Expertise: Legal Decision-Making and the Reception of Expert Evidence' [2008] Criminal Law Review 443; William E O'Brian Jr, 'Court Scrutiny of Expert Evidence: Recent Decisions Highlight the Tensions' (2003) 7 International Journal of Evidence \& Proof 172; RD Mackay and Andrew M Colman, 'Equivocal Rulings on Expert Psychological and Psychiatric Evidence: Turning a Muddle into a Nonsense' [1996] Criminal Law Review 88.

68 Law Commission, Expert Evidence in Criminal Proceedings in England and Wales, Law Com No 325 (London, TSO, 2011).

69 Criminal Practice Directions 2015 [2015] EWCA Crim 1567, CPD V Evidence 19A. Paragraph 19A.5 mentions such factors as 'the extent and quality of the data on which the expert's opinion is based', the validity of the scientific method(s) employed, soundness of inferential reasoning, statistical methodology (where salient), publication and peer review, expert disagreement, divergence from orthodox practice, etc. These criteria largely reproduce those proposed by the Law Commission, and chime with standard epistemological accounts: see eg Erica Beecher-Monas, 'The Heuristics of Intellectual Due Process: A Primer for Triers of Science' (2000) 75 New York University Law Review 1563.

70 CPD V Evidence 19A.4, citing $R$ v Dlugosz [2013] 1 Cr App R 32, [2013] EWCA Crim 2.

71 To broadly similar effect, see Tony Ward, “"A New and More Rigorous Approach" to Expert Evidence in England and Wales?' (2015) 19 International 


\section{Jurisprudential Refinements}

Expert evidence in England and Wales is increasingly regulated not only, or even mainly, by statutory tests or common law precedents, but by a variety of delegated, ancillary and informal instruments that I describe, compendiously, as 'hardworking soft law'. Some of these instruments are truly 'soft law' in the traditional jurisprudential sense, according to which - on the most conservative view - only primary legislation (Acts of Parliament) and binding precedent cases are 'law' stricto sensu. Hardworking soft law, on this conception, would include Part 19 of the Criminal Procedure Rules, ${ }^{72}$ elucidating the legal duties of expert witnesses; and associated provisions of the Consolidated Criminal Practice Directions, ${ }^{73}$ which augment the common law tests for assessing the relevance and helpfulness of expert evidence, more particularly where scientific validity or methodology are challenged. Other important sources of hardworking soft law are not really 'law' at all. These include the official instructions for trial judges in criminal cases produced by the Judicial College (materials formerly known as 'the Crown Court Benchbook', before that terminology went out of fashion), ${ }^{74}$ and guidance issued by the Forensic Science Regulator on a variety of general and more specific topics pertaining to forensic science methods, practice and regulatory standards. ${ }^{75}$ These materials are supplemented by less official sources of guidance produced by a variety of professional associations

Journal of Evidence \& Proof 228; Tony Ward, 'Expert Evidence and the Law Commission: Implementation without Legislation?' [2013] Criminal Law Review 561.

72 Criminal Procedure Rules 2015 (as amended), www.justice.gov.uk/courts/ procedure-rules/criminal/rulesmenu-2015 (accessed 31 January 2018).

73 Criminal Practice Directions 2015 [2015] EWCA Crim 1567, CPD V Evidence 19A-C.

74 Judicial College, Crown Court Compendium Part I: Jury and Trial Management and Summing Up (2017), www.judiciary.gov.uk/publications/ crown-court-bench-book-directing-the-jury-2/ (accessed 31 January 2018); superseding Crown Court Bench Book: Directing the Jury (Judicial Studies Board, 2010).

75 See in particular Forensic Science Regulator, Information: Legal Obligations, FSR-I-400 Issue 5 (Birmingham, FSR, 2017); Forensic Science Regulator, Codes of Practice and Conduct for Forensic Science Providers and Practitioners in the Criminal Justice System, Issue 4 (October 2017), available from www.gov. uk/government/organisations/forensic-science-regulator (accessed 31 January 2018). Generally, see Tully, Chapter 4 in this volume. 
and scholarly initiative. ${ }^{76}$ The direct, and more pervasively indirect, influence of this voluminous corpus of instruments and informal practice guidance, when aggregated, is belied by its lowly jurisprudential status and marginalisation in legal (and forensic science) scholarship.

Hardworking soft law operates, as it were, below the waterline of doctrinal law as presented in Evidence textbooks, but represents the ship's boiler room and main propeller. One would certainly not derive an accurate impression of the law and practice of expert witnesses in England and Wales by confining one's gaze to primary legal sources. More ambitiously, it seems to me that the task of regulating forensic science, in all its diversity, is invariably so complex that detailed frameworks for admissibility and interpretation are unlikely to be reducible to primary legislation, or even to be fully encapsulated in bulky case law. US experience is an object lesson in this regard. Rule 702 of the Federal Rules of Evidence required extensive interpretation by the US Supreme Court in its famous Daubert decision, ${ }^{77}$ which in turn opened the floodgates to a torrent of additional appeals, including two further visits to the Court in fairly quick succession. ${ }^{78}$ Admissibility doctrines

76 The most recent initiative is a set of 'Primers' to be produced under the auspices of the Royal Societies of London and Edinburgh: see Pallab Ghosh, 'UK Judges to Get Scientific Guides', BBC News, 22 November 2017, www.bbc.co.uk/news/science-environment-42057009 (accessed 31 January 2018); David Neuberger, 'Stop Needless Dispute of Science in the Courts' (2016) 531 Nature 9. The first two published primers, covering 'forensic DNA analysis' and 'forensic gait analysis', are available from https://royalsociety.org/about-us/ programmes/science-and-law/ (accessed 31 January 2018). Another project (in which I participated), sponsored by the Nuffield Foundation and the Royal Statistical Society, produced practitioner guidance (available at www.rss.org,uk/ statsandlaw) focussed on statistics, probability and forensic science: see Paul Roberts, Colin Aitken and Graham Jackson, 'From Admissibility to Interpretation: New Guidance on Expert Evidence' (2015) 179 Criminal Law \& Justice Weekly 538 and 564; Paul Roberts, Colin Aitken, Graham Jackson and Mike Redmayne, 'When the Numbers Count' (2011) 175 Criminal Law \& Justice Weekly 304 and 319.

77 Daubert v Merrell Dow, 125 L Ed 2d 469; 113 S Ct 2786 (1993).

78 Kumho Tire Co v Carmichael, 119 S Ct 1167 (1999); General Electric $v$ Joiner, 118 S Ct 512 (1997). See further, Margaret A Berger, 'The Supreme Court's Trilogy on the Admissibility of Expert Testimony' in Federal Judicial Center, Reference Manual on Scientific Evidence, 2nd edn (Washington DC, FJC, 2000); D Michael Risinger, 'Goodbye to All That, or a Fool's Errand, by One of the Fools: How I Stopped Worrying about Court Responses to Handwriting Identification (and "Forensic Science" in General) and Learned to Love Misinterpretations of Kumho Tire v Carmichael' (2007) 43 Tulsa Law Review 447; 
establish a framework for receiving scientific and other expert evidence in criminal trials, but further detailed guidance is invariably required to assist lawyers, judges and factfinders to interpret scientific findings and evaluate their probative significance in the instant case. ${ }^{79}$

A second doctrinal prerequisite to admissibility is that evidence is proffered by a genuine, properly qualified expert. Unless the witness is a legally competent expert there would be no rational basis for treating her evidence as authoritative or reliable, consistently with adjudication's rationalist foundations. English law's test of expertise is substantive, not formal: provided that the expert actually has the relevant specialist knowledge or expertise it does not matter how, when, where or why such expertise was acquired.80 Education, training and formal qualifications may demonstrate expertise, but are not necessarily required. For example, an expert could conceivably have acquired consummate skill as a lip-reader 81 or foreign language interpreter ${ }^{82}$ without obtaining any formal qualifications. However, there may be areas of forensic science or other expertise that in practice can be acquired only through formal training or accreditation; and this in itself may give rise to concern about the availability of suitably qualified experts to assist both prosecution and defence in adversarial criminal litigation. ${ }^{83}$

Lacking discipline-specific forensic science expertise, most trial judges are not well qualified to assess the competence of expert witnesses. They almost inevitably fall back on proxies such as education, qualifications, employment status and membership of relevant professional and learned societies to determine whether particular party-instructed witnesses are bona fide experts. This structural epistemic dependency opens the door

Craig Lee Montz, 'Trial Judges as Scientific Gatekeepers after Daubert, Joiner, Kumho Tire, and Amended Rule 702: Is Anyone Still Seriously Buying This?' (2001) 33 UWLA Law Review 87.

79 In the US context, also see Federal Judicial Center, Reference Manual on Scientific Evidence, 3rd edn (Washington DC, National Academies Press, 2011).

$80 R v$ Silverlock [1894] 2 QB 766, CCR.

$81 \quad R v$ Luttrell [2004] 2 Cr App R 31, CA.

82 Cf $R$ v $O$ [2010] EWCA Crim 2985, [27] ("The word "expert" is slightly strange in these circumstances because it is, of course, very far removed from medical expertise or scientific or commercial expertise, but nevertheless there is no reason why a local person may not have expertise in a local dialect ...').

83 As the Court of Appeal observed in $R v$ Smith (Peter) [2011] 2 Cr App R 16, [2011] EWCA Crim 1296 (querying the apparently 'closed shop' arrangements for training fingerprint examiners in the UK). 
to well-documented forensic abuses, especially charlatanism ${ }^{84}$ and overreaching, 85 respectively items [6] and [7] on the critical 'top 20' countdown.

Questions of admissibility do not exhaust the evidentiary issues posed by expert evidence. Once evidence has been admitted into a criminal trial, the question then becomes: what should the findfinder make of it? What is its probative value? How does it bear on the contested issues and relate to other evidence in the case? In England and Wales, these are jury questions in trials on indictment, and we never really know how a particular jury arrived at its verdict. But juries are not left to their own devices in interpreting and assessing evidence. By longstanding tradition, trial judges in England and Wales sum up on the facts as well as the applicable law $^{86}$ and, in general, play a more proactive role in trial management than the classic 'umpireal model' 87 of judging associated with adversarial trials might suggest. They devote considerable time and energy to formulating (increasingly elaborate) summings-up, advising and, in some respects, instructing juries how they might, should, must or must not think about or utilise particular kinds of evidence. Notoriously fallacious or 'prejudicial' inferential reasoning is singled out for warnings and reminders in accordance with a phalanx of 'forensic reasoning

84 Verified sightings are notably few in England and Wales, but see Jamie Doward, 'How Police Put their Faith in the "Expert" Witness who was a Fraud', The Observer, 23 March 2008; Karen McVeigh, "The £250,000 "Psychologist" who Fooled the Courts for 27 Years', The Guardian, 22 February 2007; Zakaria Erzinçlioglu, 'British Forensic Science in the Dock' (1998) 392 Nature 859 (30 April); RHL Disney, 'Fraudulent Forensic Scientists' (2002) 45 Journal de Médecine Légale Droit Médical 225. Cf Mick Hamer, 'How a Forensic Scientist Fell Foul of the Law' (1981) 91 New Scientist 575.

85 A textbook illustration is $R v$ Clark [2003] EWCA Crim 1020; Meadow $v$ General Medical Council [2007] QB 462, [2006] EWCA Civ 1390. See Joshua Rozenberg, 'Pathologist Misled Appeal Judges in Sally Clark Case', Daily Telegraph, 12 April 2003; Richard Horton, 'In Defence of Roy Meadow' (2005) 366 The Lancet 3 (2 July).

$86 \quad R v$ Cohen and Bateman (1909) 2 Cr App R 197, CCA; McGreevy v DPP [1973] 1 WLR 276, 281, HL. For (common law) comparative context, see Paul Marcus, 'Judges Talking to Jurors in Criminal Cases: Why US Judges Do it So Differently from Just About Everyone Else' (2013) 30 Arizona Journal of International and Comparative Law 1.

87 Marvin E Frankel, 'The Search for the Truth: An Umpireal View' (1975)

123 University of Pennsylvania Law Review 1031. 
rules'. ${ }^{88}$ Several tailored warnings and directions pertain specifically to expert evidence, ${ }^{89}$ notably to aspects of DNA profiling. ${ }^{90}$

\section{Three Institutional Developments}

Two additional features of the broader institutional landscape of contemporary British forensic science are salient to examining the competence of forensic scientists and other expert witnesses and assessing the validity and reliability of their evidence. Both developments are children of austerity politics; and both, in my opinion, demonstrate the inadequacy of market-based models of forensic science provision and regulation. ${ }^{91} \mathrm{~A}$ third institutional development has somewhat ameliorated the combined impact of the first two.

The Council for the Registration of Forensic Practitioners (CRFP) was created in 1999, after long discussion and planning, as a direct response to the 'charlatanism' worry (number [6] in my 'top 20'), and with an eye to mitigating problems of junk science [1], invalidity [2], non-scientific methodology [4], human error [5], overreaching [7] and adversarial deficit [14], amongst other well-rehearsed shortcomings of expert witness testimony. ${ }^{92}$ Although registration with CRFP was never a formal prerequisite of legal competency for expert witnesses, it was anticipated that

88 See Roberts and Zuckerman, above n 29, ch 15.

89 See eg $R v$ Henderson [2010] 2 Cr App R 24, [2010] EWCA Crim 1269, [215]-[220]; $R$ v Flynn and St John [2008] 2 Cr App R 20, [2008] EWCA Crim 970; $R$ v Luttrell [2004] 2 Cr App R 31, [2004] EWCA Crim 1344, [42]-[43]:

'The general principle ... is that a "special warning" is necessary if experience, research or common sense has indicated that there is a difficulty with a certain type of evidence that requires giving the jury a warning of its dangers and the need for caution, tailored to meet the needs of the case. This will often be the case where jurors may be unaware of the difficulty, or may insufficiently understand it. The strength of the warning and its terms will depend on the nature of the evidence, its reliability or lack of it, and the potential problems it poses.'

$90 \quad R v$ Doheny and Adams [1997] 1 Cr App R 369, CA; $R v$ Reed and Reed; $R v$ Garmson [2010] 1 Cr App R 23, [2009] EWCA Crim 2698. See further, Roberts, above n 42; Mike Redmayne, Expert Evidence and Criminal Justice (Oxford, Oxford University Press, 2001) ch 4.

91 Paul Roberts, 'What Price a Free Market in Forensic Science Services? The Organization and Regulation of Science in the Criminal Process' (1996) 36 British Journal of Criminology 37.

92 For a potted history, see Alan Kershaw, 'Professional Standards, Public Protection and the Administration of Justice' in Fraser and Williams (eds), above n 12. 
CRFP membership would become an authentic badge of certified expertise in which the courts would increasingly come to invest credibility, perhaps to the point at which CRFP registration would become a presumptive requirement of admissibility. But CRFP never had time to generate this elevated level of judicial confidence: despite promising early activity, within a decade it was gone. Its fate was sealed because, despite significant public funding in the early years, it could not generate enough subscription income to be financially self-sustaining as specified by its business model. ${ }^{93}$ This (expensive) failed experiment proves that a durable system of expert accreditation would have to be funded by the state, either directly as part of a ministerial department or indirectly as a semi-independent agency. There is no realistic prospect of reanimation for the foreseeable future, probably irrespective of the political colour of incumbent government. Police, prosecutors, lawyers and courts will have to continue to muddle along, as they always have, drawing on local knowledge and personal experience to locate, instruct and verify competent and appropriately qualified experts.

A second major institutional feature of contemporary UK forensic science is the closure of the Forensic Science Service (FSS), a victim of the then newly elected Coalition Government's orgy of quango-burning in 2010. The FSS ceased operational casework in 2012. ${ }^{94}$ In retrospect, this catastrophe had been on the cards for a long time, possibly ever since the FSS became a 'Next Steps' semi-autonomous agency of the Home Office in 1991, and thereafter was subjected to increasingly stringent market discipline. ${ }^{95}$ When, with slow motion car crash predictability, it became clear that the FSS could not sustain itself as a viable commercial enterprise (according to some contrived funding formula), the doors were closed on arguably the world's finest forensic science provider, and its

93 ' $[$ TThe goal of a self-funding independent accreditation body had not been achieved and the company was facing a long-term shortfall of funding, because the registration income did not match the expenditure ... This was likely to become considerably worse because of the withdrawal of support for the registration process by police forces': HC Debs, 20 April 2009, c 157W (written ministerial answer by Jacqui Smith MP).

94 House of Commons Science and Technology Committee, Forensic Science, Second Report of Session 2013-14, HC 610 (London, TSO, 2013).

95 Christopher J Lawless, 'Policing Markets: The Contested Shaping of Neo-Liberal Forensic Science' (2011) 51 British Journal of Criminology 671; Christopher J Lawless and Robin Williams, 'Helping with Inquiries or Helping with Profits? The Trials and Tribulations of a Technology of Forensic Reasoning' (2010) 40 Social Studies of Science 731. 
invaluable human and material resources were dissipated. ${ }^{96}$ It is already quite clear that closing the FSS was a terrible blunder, possibly even in narrow financial terms. This sorry episode demonstrates (if further demonstration were needed) the irrationality of applying rigid market models and solutions to spheres of human activity that cannot be understood or appreciated in purely economic terms. ${ }^{97}$ It is no surprise to me that the National Audit Office subsequently reported that the UK market in commercial forensic science provision suffers from a lack of transparency and potentially serious structural weaknesses, ${ }^{98}$ or that the House of Commons Science and Technology Committee is worried about the paucity of fundamental research and the sustainability of capacity, professional training and educational provision in UK forensic science. ${ }^{99}$ Markets simply cannot deliver essentially public goods like high quality forensic science, because there is no institutional 'consumer' qualified and motivated to discipline the market in alignment with the public interest in the administration of justice.

The rational incentive for the police, themselves under tight budgetary constraint, is to avoid the expense of scientific support whenever they can get away with doing so (eg where investigators can secure a confession without scientific evidence), and in other cases drive down costs by commissioning only the minimum forensic service to advance strategic

96 This is an (over)simplified version of a more complex, institutionally nuanced story: see Tim J Wilson and Angela MC Gallop, 'Criminal Justice, Science and the Marketplace: The Closure of the Forensic Science Service in Perspective' (2013) 77 Journal of Criminal Law 56.

97 For general critique, see Darryl K Brown, Free Market Criminal Justice (New York, Oxford University Press, 2016); Yanis Varoufakis, Talking to my Daughter about the Economy: A Brief History of Capitalism (London, Bodley Head, 2017); Allen Buchanan, Ethics, Efficiency and the Market (Totowa NJ, Rowman \& Littlefield, 1988).

98 According to a National Audit Office (NAO) review, '[p]olice forces are undertaking more forensics work internally and this could undermine the market. Expenditure on private sector forensic services through the framework has declined significantly ... Private sector companies are concerned that police force laboratories may be able to operate more cheaply by using police premises without charge or by delaying meeting UK accreditation standards ...': Briefing for the House of Commons Science and Technology Committee: The Home Office's Oversight of Forensic Services (December 2014), para.7, www.nao.org. uk/report/home-offices-oversight-forensic-services/ (accessed 31 January 2018).

99 House of Commons Science and Technology Committee, Forensic Science, Second Report of Session 2013-14, HC 610 (London, TSO, 2013); The Forensic Science Service, Seventh Report of Session 2010-12, HC 855 (London, TSO, 2011). 
objectives in the investigation. These market incentives are not obviously truth-conducive for criminal adjudication. Why, according to market logic, should police squander their budgets on scientific tests unless the anticipated results are more likely to advance the investigation than to assist the defence? Strategic behaviour encouraged by this incentive structure is almost certain to be exacerbated by the advent of 'streamlined forensic reporting', ${ }^{100}$ another unabashed cost-cutting measure which enables the police and the prosecution to extract maximum evidential value from bare summaries of forensic findings (which might actually be prepared by administrators rather than qualified experts). ${ }^{101}$ Taking scientific provision 'in house', moreover, is a recipe for falling standards and a major risk factor for confirmation bias in scientific testing and reported results. US experience indicates that the worst abuses in forensic science invariably take place in police labs estranged from supportive cultures of scientific rigour and meaningful regulatory oversight. ${ }^{102} \mathrm{I}$ am not suggesting that British forensic science will necessarily replicate the worst of these horrors. But a wise policymaker would strive to avoid institutional structures with known vulnerabilities to distortion, bias and corrosive bad practice.

100 Oriola Sallavaci, 'Streamlined Reporting of Forensic Evidence in England and Wales: Is it the Way Forward?' (2016) 20 International Journal of Evidence \& Proof 235.

101 Ibid 245-6. The Forensic Science Regulator has described aspects of SFR practice as 'troubling' and 'completely unacceptable', and warned that procedural compliance must improve 'to ensure that the process operates properly - or not at all': Forensic Science Regulator, Annual Report: November 2016November 2017 (Birmingham, FSR, 2018) para 2.9. Also see Tully, Chapter 4 in this volume.

102 Paul C Giannelli, 'The Abuse of Scientific Evidence in Criminal Cases: The Need for Independent Crime Laboratories' (1997) 4 Virginia Journal of Social Policy and the Law 439; Paul C Giannelli, 'False Credentials' (2001) 16-Fall Criminal Justice 40; Paul C Giannelli, 'Houston! We Have a Problem!' (2006) 21-Sum Criminal Justice 40; Paul C Giannelli, 'Alchemy, Magic, and Forensic Science' (2006) 21-Fall Criminal Justice 50; Paul C Giannelli, 'Wrongful Convictions and Forensic Science: The Need to Regulate Crime Labs' (2007) 86 North Carolina Law Review 163; Paul C Giannelli, 'Daubert and Forensic Science: The Pitfalls of Law Enforcement Control of Scientific Research' [2011] University of Illinois Law Review 53; Simon A Cole, 'Acculturating Forensic Science: What is "Scientific Culture" and How Can Forensic Science Adopt It?' (2010) 38 Fordham Urban Law Journal 435; Itiel E Dror, 'Practical Solutions to Cognitive and Human Factor Challenges in Forensic Science' (2013) 4 Forensic Science Policy and Management 1. 
One positive institutional innovation of the last decade has been the creation of the office of Forensic Science Regulator to establish and monitor minimum standards of product quality and service delivery in UK forensic sciences. The two office holders to date have embarked on an energetic programme of standard-setting, compilation of codes of practice, topical reviews, focussed inquiries into particular problematic issues and cases, and information synthesis and dissemination through the Regulator's excellent website and periodic newsletters. ${ }^{103}$ It must, however, remain an open question whether the Regulator, armed predominantly with the power of rational persuasion but limited authority to force compliance, ${ }^{104}$ has really been able to guarantee a properly functioning forensic market. The diversity of modern forensic science disciplines, animated by a corresponding variety of entrenched habits of thought, operational protocols and institutional powerbases, represents a complex and challenging environment for any would-be regulator. Ten years on, the labours of the Forensic Science Regulator are still a work in progress. ${ }^{105}$

\footnotetext{
103 www.gov.uk/government/organisations/forensic-science-regulator (accessed 31 January 2018).

104 The Government's published Forensic Strategy promised proposals to underpin the Regulator's powers and Codes of Practice with explicit statutory authority: Home Office, Forensic Science Strategy, Cm 9217 (March 2016), [44]. No timetable was indicated, however, and the House of Commons Science and Technology Committee was subsequently 'left with serious doubts about the Government's commitment to deliver this': Forensic Science Strategy, Fourth Report of Session 2016-17, HC 501 (London, TSO, 2016), [63].

105 This is also the Regulator's own self-assessment in periodic annual reports. 'Much progress has been made towards compliance, but significant areas of risk remain': Forensic Science Regulator, Annual Report: November 2014November 2015 (Birmingham, FSR, 4 December 2015) 4. '[Market] instability presents a significant risk to the quality of forensic science work. ... As the scope of activities requiring quality management increases, the quality management systems employed are reaching their capacity limits. ... [I]t is becoming clear that not all police forces are fully committed to reaching the required standards. ... Statutory powers for the Regulator are now needed in order that those organisations that have not committed the resource and effort required to attain the standards can be induced to do so': Forensic Science Regulator, Annual Report: November 2015-November 2016 (Birmingham, FSR, 6 January 2017) 6-8. Also see Ward (Chapter 3) and Tully (Chapter 4) in this volume.
} 


\section{INTELLECTUAL RESOURCES FOR FORENSIC SCIENCE}

Previous sections of this chapter have elucidated the normative foundations, conceptual scaffolding and institutional structures of forensic science evidence. Another vital piece of the puzzle concerns the intellectual resources of forensic science. ${ }^{106}$

The 'intellectual resources' of forensic science potentially comprise a broad and diverse miscellany. The discipline-specific knowledges and methods constituting particular forensic specialisms (crime scene examination, DNA profiling, fingerprinting, trace examination, drugs analysis, etc) are core intellectual resources, as are relevant segments of their respective parent sciences (genetics, biology, physics, chemistry, engineering, computer science, etc). Less obviously, the generic logic and techniques of scientific method are key intellectual resources for forensic science. This covers such fundamental matters as methods of empirical data collection and experimentation and the logics of inductive inference and syllogistic deduction. ${ }^{107}$ Widen the laboratory lens, and we should also consider contextual socio-legal and criminological aspects of forensic inquiry and evidence production and its judicial applications. ${ }^{108}$ The normative foundations of criminal justice equally constitute part of forensic science's intellectual resources in the wider sense. Finally, the very ways in which we conceptualise 'forensic science' and characterise its core knowledges, methods and applications are important intellectual resources. Such disciplinary classifications and their internal taxonomies inform thinking and conduct, especially when such ideas become embedded in institutional structures and routine operational practices, and in this way solidify and propagate, as they typically do.

106 This section draws on Roberts, above $\mathrm{n} 25$ (proposing an analytical model of forensic science comprising: (1) normative foundations; (2) institutional frameworks; and (3) intellectual resources).

107 See Roberts (ed), above n 12, Part III; Bernard Robertson, GA Vignaux and Charles EH Berger, Interpreting Evidence: Evaluating Forensic Science in the Courtroom, 2nd edn (Chichester, Wiley, 2016); Michael J Saks, 'Forensic Identification: From a Faith-Based "Science" to a Scientific Science' (2010) 201 Forensic Science International 14; Michael J Saks and Jonathan J Koehler, 'The Coming Paradigm Shift in Forensic Identification Science' (2005) 309 Science 892.

108 Andy Williams, Forensic Criminology (Abingdon, Routledge, 2016); Christopher Lawless, Forensic Science: A Sociological Introduction (Abingdon, Routledge, 2016). 
Adumbrating the intellectual resources of forensic science is plainly a massive undertaking, which this chapter can only gesture towards. Technologies of data interpretation and evidence production and transmission merit emphasis, for two reasons. First, it seems to me that such technologies must anchor the intellectual foundations of a generic forensic science. Whilst particular forensic specialisms are in part distinguished by their own specialist knowledges and techniques, every forensic application of science has a shared interest in the interpretation of analytical results or other empirical findings ('data') leading to the production and communication of judicial evidence. This is the constitutive aspiration that qualifies science as forensic. So technologies of data interpretation and evidence production are one, and possibly one of the most significant, unifying threads in an otherwise very diverse multidisciplinary patchwork. ${ }^{109}$ They are also a focus of interdisciplinary inquiry and overlapping professional interest, presenting an urgent need for shared concepts and a tractable language to facilitate meaningful communication across disciplinary boundaries. Secondly, much promising work has already been done in this area, and it is currently the topic of lively domestic and international debates between forensic scientists and other criminal justice professionals. ${ }^{110}$

Any contemporary discussion of data interpretation and evidence analysis in the forensic sciences would seem glaringly incomplete without reference to Bayes' theorem. ${ }^{11}$ Although I have collaborated with 'the Bayesians' and co-authored publications advocating this approach, ${ }^{112} \mathrm{my}$ fundamental commitment is to methodological pluralism. In this chapter, I

109 See further, Paul Roberts, 'The New Interdisciplinary Forensic Science' (2016) 43 Journal of Law and Society 647.

110 See in particular, ENFSI Guideline for Evaluative Reporting in Forensic Science, v.3.0 (8 March 2015), www.enfsi.eu/news/enfsi-guideline-evaluativereporting-forensic-science (accessed 31 January 2018); Colin Aitken (ed), Special Issue: Papers on the R v T Debate (2012) 11(4) Law, Probability \& Risk 255; Association of Forensic Science Providers, 'Standards for the Formulation of Evaluative Forensic Science Expert Opinion’ (2009) 49 Science \& Justice 161.

111 Cf Richard Lempert, 'Some Caveats Concerning DNA as Criminal Identification Evidence: With Thanks to the Reverend Bayes' (1991) 13 Cardozo Law Review 303.

112 In particular, Graham Jackson, Colin Aitken and Paul Roberts, Case Assessment and Interpretation of Expert Evidence, RSS Practitioner Guide No 4 (London, Royal Statistical Society, 2014); Colin Aitken, Paul Roberts and Graham Jackson, Fundamentals of Probability and Statistical Evidence in Criminal Proceedings, RSS Practitioner Guide No 1 (London, Royal Statistical Society, 2010). See above n 76. 
mainly want to emphasise the importance and practical challenges of developing effective technologies of data analysis and evidence production, rather than endorsing any particular model. Four further general points can usefully be made.

First, 'Bayes' theorem' is nothing more nor less than a relatively straightforward extrapolation of elementary probability axioms. ${ }^{113}$ On a good day, I can even reproduce the theoretical proof myself. So one cannot rationally be 'against' Bayesianism in any abstract sense, any more than one can be against arithmetic or gravity. They are facts of life. But this in itself is almost beside the point, because the real question is whether Bayes' theorem or 'Bayesian reasoning' more generally has any useful forensic or judicial applications, and if so, what they are. There is quite an extensive legal literature, predominantly in US law reviews going back to the early 1970 s, ${ }^{114}$ exploring these questions. There is, however, a threshold terminological difficulty, inasmuch as 'Bayesianism' and 'Bayesian reasoning' have come to stand for a variety of related claims and propositions, and there is considerable confusion in the literature and wider professional discourses about what is entailed by this kind of orientation to forensic science. For example, whereas some proponents are mainly concerned with the instrumental utility of likelihood ratios, others are committed to much stronger programmes of Bayesian rationality as a tool of policymaking in general and law reform in particular. My first piece of advice would be to always ask for a clear specification of terms and assumptions whenever one encounters the B-word.

113 For clear explanations, see Richard O Lempert, 'Analyzing Relevance' (1977) 75 Michigan Law Review 1021; Bernard Robertson and GA Vignaux, 'Probability: The Logic of the Law' (1993) 13 Oxford Journal of Legal Studies 457; Mike Redmayne, 'Bayesianism and Proof' in Michael Freeman and Helen Reece (eds), Science in Court (Farnham, Ashgate, 1998).

114 Debate was sparked by the demonstrably fallacious reasoning presented to the trial court in People v Collins, 68 Cal 2d 319, 66 Cal Rptr 497 (1968): see Laurence H Tribe, 'Trial by Mathematics: Precision and Ritual in the Legal Process' (1971) 84 Harvard Law Review 1329; Michael O Finkelstein and William B Fairley, "A Comment on "Trial by Mathematics"” (1971) 84 Harvard Law Review 1801. More recently, see Ron Allen and Mike Redmayne (eds), Bayesianism and Juridical Proof (1997) 1(5) International Journal of Evidence \& Proof 253; Ron Allen and Paul Roberts (eds), Special Issue on the Reference Class Problem (2007) 11(4) International Journal of Evidence \& Proof 243. 
A second important clarification is that Bayesianism might theoretically be applied to a range of different tasks in the administration of criminal justice. It is therefore essential to be clear about the particular applications one is addressing. For example, courts in England and Wales have implacably set their face against teaching jurors in criminal trials to use Bayes' theorem in their assessment of scientific or any other evidence. ${ }^{115}$ But this has no direct bearing on analytically discrete policy choices, such as whether forensic scientists should employ Bayesian logic when advising criminal investigators or in interpreting their own analytical results. There has been some confusion in extrapolating the Court of Appeal's disparaging remarks about Bayesianism ${ }^{116}$ to contexts or applications which were probably not intended by the Court, and at any rate do not fall within the scope of authoritative legal precedent. ${ }^{117}$

Thirdly, Bayesian logic exhibits admirable conceptual strengths, which ought to be recognised and incorporated into all forensic technologies of data interpretation and judicial evidence production, be they Bayesian, 'Bayesian' or non-Bayesian. One strength is the insistence that the logical force of evidence can only be rationally judged relative to its impact on rival hypotheses or propositions, that is, by the likelihood ratio for the evidence. Simply, evidence does not support the prosecution's case if its ex ante likelihood is greater on the assumption that the defence case is true. The inherent relativity of probative value is an essential insight of Bayesian approaches, with allied conceptual virtues. In order to formulate apposite and robust rival propositions it is necessary to think very carefully about the particular questions ${ }^{118}$ to which evidence is addressed and to encapsulate evidential propositions in precise language. Linguistic precision and evidential relevancy are highly prized in legal theory and practice. Bayesianism also demands attention to ex ante assumptions and expectations ('prior probabilities'), as a rational baseline against which to judge the meaning and force of new data. This draws attention to statistical 'base rates' and other information which human cognitive

$115 R v$ Adams (No 2) [1998] 1 Cr App R 377 (CA); $R v$ Adams [1996] 2 Cr App R 467 (CA).

116 Especially in $R v T$ [2011] 1 Cr App R 9, [2010] EWCA Crim 2439, [86]-[87] (asserting that 'in the area of footwear evidence, no attempt can realistically be made in the generality of cases to use a formula to calculate the probabilities. The practice has no sound basis').

117 See further, Redmayne et al, above n 66.

118 Including the 'level' of proposition: see Jackson, Aitken and Roberts, above n 16. Also see Carr et al, Chapter 5 in this volume. 
machinery is not well-adapted to process without directed effort, ${ }^{119}$ and which ought to instil a more generally critical attitude to the 'common sense' assumptions underpinning naturalistic inferential reasoning. Bayesian approaches helpfully underline the importance of the way in which analytical findings are communicated to decision-makers. To insist that expert witnesses should state the probability of the evidence rather than the probability of a proposition sounds obscure when first encountered, but it expresses fidelity to a foundational precept of common law criminal procedure. The expert's job is to report evidential findings and help factfinders to evaluate their probative significance, without preempting factual determination. It is the constitutionally mandated ${ }^{120}$ function of jurors, judges and magistrates to assess the strength of the prosecution's case in the light of all the evidence presented at trial. ${ }^{121}$

Whilst properly acknowledging these conceptual strengths, there remain significant areas of difficulty and disagreement in the application of Bayesian methods in forensic science. This is my fourth generic observation. One problem is that Bayesians tend to be so fond of their basic conceptual schema that they insist on reinterpreting conventional language in terms of 'priors', likelihood ratios and posterior probabilities. This is not, in my opinion, always helpful or illuminating. By analogy, it is possible to translate linguistic expressions into symbolic logic, but this move is not necessarily helpful in practical applications or meaningful for contextual language-users. A related problem is that, despite the inherent relativity of evidential value in any formalisation of conditional probability, Bayesians conceptualise and talk about 'probative value' as though it were a rational property of likelihood ratios. ${ }^{122}$ This is a source

119 Daniel Kahneman, Thinking, Fast and Slow (London, Penguin, 2011); David H Kaye, Valerie P Hans, B Michael Dann, Erin Farley and Stephanie Albertson, 'Statistics in the Jury Box: How Jurors Respond to Mitochondrial DNA Match Probabilities' (2007) 4 Journal of Empirical Legal Studies 797; Michael J Saks and Robert F Kidd, 'Human Information Processing and Adjudication: Trial by Heuristics' (1981) 15 Law and Society Review 123.

$120 R v$ Twomey [2009] 2 Cr App R 25, [10] (Judge CJ observing that, '[i]n this country trial by jury is a hallowed principle of the administration of criminal justice. It is properly identified as a right ...').

121 ' $[\mathrm{I}] \mathrm{n}$ criminal trials cases are decided by juries, not by experts': $R v$ Brennan [2015] 1 WLR 2060, [2014] EWCA Crim 2387, [43] (applying the longstanding common law rule expressed in Davie $v$ Edinburgh Magistrates [1953] SC 34, but also emphasising the importance of rationality in adjudication).

122 Here is one representative illustration of the genre: '[T]he value of the evidence itself is the same no matter what [prior probabilities] are used. As such 
of much confusion and frustration, because common lawyers typically do not think about probative value in this way. On a standard jurisprudential account, probative value is just that evidential weight that jurors will attribute $^{123}$ to particular evidence once it has been tested in the trial and factored into their deliberations. This is a socio-psychological conception of 'probative value', which lawyers, judges or any other courtroom experts may try to anticipate, but cannot displace or override according to legal orthodoxy. The scope for common lawyers and Bayesians to talk past one another about 'probative value' is obvious once this terminological discrepancy is pointed out, but it is currently too little appreciated and consequently a prevalent mischief-maker.

A further set of important, and controversial, questions concerns the manner in which forensic science conducted within a Bayesian paradigm should be presented to factfinders in court, for example, as numerical likelihood ratios, conditional probabilities or verbal expressions of evidential weight. ${ }^{124}$ Here, I will say only that what works best for forensic scientists in producing their analytical findings will not necessarily translate directly, or at all, into the best means of communicating these findings to lay audiences. ${ }^{125}$ These translational issues pose acute

it can be used to make objective statistical inference about the propositions in a case ... The value of evidence is often called the "likelihood ratio" ...': Anders Nordgaard and Birgitta Rasmusson, 'The Likelihood Ratio as Value of Evidence: More than a Question of Numbers' (2012) 11 Law, Probability \& Risk 303, 304. This way of thinking is embedded in standard probabilistic conceptions of probative value: see Colin Aitken and Franco Taroni, Statistics and the Evaluation of Evidence for Forensic Scientists, 2nd edn (Chichester, Wiley, 2004).

123 Or, on a normative variation, the weight that a rational jury should attribute to the evidence. But in any event, the lawyers' conception is relative to all of the evidence presented in the trial, and in light of the way in which the case is being run.

124 The options were insightfully canvassed by Mike Redmayne, above $n$ 90, chs $3-4$.

125 See eg Jan de Keijser and Henk Elffers, 'Understanding of Forensic Expert Reports by Judges, Defense Lawyers and Forensic Professionals' (2012) 18 Psychology, Crime \& Law 191 (reporting widespread misunderstanding and misinterpretation of scientific findings by Dutch legal professionals, but also significant errors by forensic scientists). Also see Dawn McQuiston-Surrett and Michael J Saks, 'The Testimony of Forensic Identification Science: What Expert Witnesses Say and What Factfinders Hear' (2009) 33 Law and Human Behavior 436; Jonathan J Koehler, 'The Psychology of Numbers in the Courtroom: How to Make DNA-Match Statistics Seem Impressive or Insufficient' (2001) 74 Southern California Law Review 1275; Jonathan J Koehler, 'On Conveying the Probative 
questions for legal policymaking and forensic practice that can be answered satisfactorily - to the extent that they can be - only through intelligent interdisciplinary discussion, ultimately implicating broader social expectations of forensic science and the normative underpinnings of criminal adjudication.

\section{CONCLUSIONS}

This chapter aimed to make progress towards 'making sense of forensic science evidence'. Its objective is self-consciously modest - and not only because subsequent chapters of this book will take up the torch and cast their own illumination. Forensic science operates within complex and dynamic institutional environments, presenting a multitude of theoretical and practical issues for scholarship, policymaking and professional practice. Actively 'problematising' these issues is inevitably perspectival and interest-driven. Legal scholars in the common law world have tended to view forensic science through the rather narrow and potentially distorting lens of evidentiary rules of admissibility. The US Supreme Court's landmark decision in Daubert ${ }^{126}$ has understandably attracted exhaustive scholarly attention, not only within the USA itself but also in innumerable comparative commentaries. ${ }^{127}$ However, refining admissibility doctrines is only one small piece of the puzzle; and after all, not necessarily an especially significant piece. ${ }^{128}$

Value of DNA Evidence: Frequencies, Likelihood Ratios, and Error Rates' (1996) 67 University of Colorado Law Review 859.

126 Daubert v Merrell Dow, 125 L Ed 2d 469; 113 S Ct 2786 (1993).

127 See eg Gary Edmond, Emma Cunliffe, Simon A Cole and Andrew J Roberts, 'Admissibility Compared: The Reception of Incriminating Expert Evidence (ie Forensic Science) in Four Adversarial Jurisdictions' (2013) 3 University of Denver Criminal Law Review 31; Petra van Kampen and Hans Nijboer, 'Daubert in the Lowlands' (1997) 30 UC Davis Law Review 951; Paul Roberts, 'The Admissibility of Expert Evidence: Lessons from America' (1996) 4 Expert Evidence 93; Stephen J Odgers and James T Richardson, 'Keeping Bad Science Out of the Courtroom: Changes in American and Australian Expert Evidence Law' (1995) 18 University of New South Wales Law Journal 108.

128 Cf Craig Lee Montz, 'Trial Judges as Scientific Gatekeepers after Daubert, Joiner, Kumho Tire, and Amended Rule 702: Is Anyone Still Seriously Buying This?' (2001) 33 UWLA Law Review 87; Edward K Cheng and Albert Yoon, 'Does Frye or Daubert Matter? A Study of Scientific Admissibility Standards' (2005) 91 Virginia Law Review 471. 
This chapter began by presenting a 'top 20 countdown' of issues, problems and criticisms of forensic science (and other expert) evidence which have regularly featured in legal scholarship spanning many decades. Even this glib summary conveys the multidimensional nature of the forensic science 'problematic'. Its further exploration begins to fathom the intransigence of the issues (experienced by seasoned observers as eternal recurrence) and expose the magnitude of the regulatory challenges they present. Long before - as well as after - admissibility determinations are made in criminal trials, forensic science evidence must be interpreted and evaluated, by various actors and for a range of institutional purposes. Making sense of the larger picture demands interdisciplinary exploration of a host of dynamically intersecting variables. This chapter highlighted and addressed: the rationality of epistemic reliance on scientific expertise; 129 the organisation and regulation of forensic science services; the normative values and procedural frameworks of criminal adjudication in particular legal jurisdictions; and the underpinning intellectual resources of forensic science.

Sense-making is a pervasive human activity, essential to wellinformed, reflective decision-making and meaningful purposive conduct. Rational agency, moral responsibility and psychological integration (the sense of self) all depend on it. ${ }^{130}$ These existential profundities are concretised in the quotidian experiences and conduct of criminal process. Forensic scientists need to make sense of their analytical findings before providing expert advice or witness statements to criminal justice professionals. Investigators and prosecutors routinely grapple with the sense of scientific information in their strategic decision-making, as do defence lawyers in advising their clients. Defence lawyers may be assisted in this endeavour by their own experts, whose job it is to check primary forensic findings, and possibly offer alternative explanations - competing senses for them. Trial judges ruling on admissibility, and factfinders evaluating the evidence presented in trials, are all in the sense-making business. Appeals and post-conviction procedures are often influenced by interpretations placed on ostensibly new scientific information. Rather than being

129 Also see Gary Edmond, 'Forensic Science Evidence and the Conditions for Rational (Jury) Evaluation’ (2015) 39 Melbourne University Law Review 77.

130 Generally, see Joseph Raz, Engaging Reason (Oxford, Oxford University Press, 2001); Derek Parfit, Reasons and Persons (Oxford, Oxford University Press, 1984). 
scholarship's exclusive preserve, sense-making is only its most characteristic, explanatory activity. Generally speaking, scholarship ${ }^{131}$ does not directly produce, audit or regulate forensic casework, nor does it investigate, prosecute, defend, testify, manage or adjudicate criminal cases. But academic research and scholarship can - and in my view, should indirectly contribute to all of these essential components of the administration of justice by helping policymakers and practitioners to make better sense of forensic science evidence.

131 Of course, individual scholars may do so, but this only shows that scholars sometimes concurrently participate in policy or casework. Rarely, policy work could be scholarship (cf Paul Roberts and Candida Saunders, 'Piloting PTWI: A Socio-Legal Window on Prosecutors' Assessments of Evidence and Witness Credibility' (2010) 30 Oxford Journal of Legal Studies 101), but this is not standard, at least not in legal scholarship, as I understand it. At any rate, the distinction I am drawing is one of activity and function, not job title. 